\title{
MASTRR
}

\section{ORTAP: A Nuclear Steam Supply System Simulation for the Dynamic Analysis of High Temperature Gas Cooled Reactor Transients}

\author{
J. C. Cleveland \\ R. A. Hedrick \\ S. J. Ball \\ J. G. Delene
}

Prepared for the U.S. Nuclear Regulatory Commission

Uffice of Nuclear Regulatory Research Under Interagency Agreement ERDA 40-551-75 
ORRL/NUREG/TM-78

Dist. Category NRC-8

Contract No. H-7405-eng-26

Engineer ing Technology Division

ORTAP: A NUCLEAR STEAM SUPPLY SYSTEM SIMULATION

FOR THE DYNAMIC AKALYSIS OF HIGH TEMPERATURE GAS COOLED REACTOR TRAHSIENTS
J. C. Cleveland
S. J. Ball
R. A. Hedrick
J. G. Delene

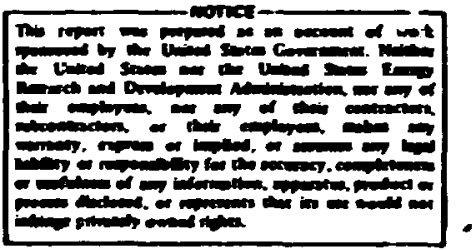

Manuscript Completed - August 10, 1977

Date Published - September 1977

NOTICE: This document contains information of a preliminary nature. It is subject to revision or correction and therefore does not represent a final report.

\section{Prepared for the}

U. S. Nuclear Regulatory Commission

Office of Nuclear Regulatory Research

Under Interagency Agreement ERDA 40-551-75

Prepared by the

OAK RIDGE MATIONAL LABORATORY

Oak R1dge, Tennessee 37830

operated by

UNION CARBIDE CORPORATION

for the

ENIRGY RESEARCH AND DEVELOPMENT ADMTNISTRATION 
111

\section{ACIRTALEDGIDNS}

The authors would like to express their appreciation to J. C. Conkiln for his review and heipful suggestions, and to Paula Renf:"s for preparing the anuscript and generating the plots for the sample transient. 
CONTENTS

Page

Abstract ........................ vil

Nomenclature ....................... 1x

1. Introduction ..................... 1

2. Description of the HTGR Nuclear Steam Supply System . . . 3

3. Component simulation .................. 11

3.1 Core Model .................... 11

3.2 Reheater and Steam Generator Mode1 ......... 17

3.3 Turblne Generator Plant Model ............ 19

3.4 Helium Circulator and Circulator Turoine Model . . . 29

3.5 Turbine Bypass, Desuperheater and Flash Tank Models . . 32

4. Control System Simulation ............... 34

5. Coupling of Compcnent Models In System Simulation . . . . 36

6. Sample Transtent ................... 40

7. Future Applications of ORTAP . . . . . . . . . . . 49

8. References ..................... 49

Appendix: Input Instructions and Sample Input Listing . . . . 52 


\section{$\therefore$}

vi1

ABSTRACT

ORTAP was developed to predict the dymanic behavior of the high temperature gas cooled reactor (BTCR) Nuclear Stean Supply Systen for normal operational transfents and postulated accident conditions. It was developed for the luclear Regulatory Comission (NRC) as an Independent means of obtaining conservative predictions of the transient response of HTGRs over a wide range of conditions. The approach has been tc bulld susficient detall into the component models so that the coupling between the primary and secondary systems can be accurately represented and so that transients which cover a wide range of conditions can be simulated.

System components which are modeled in ORTAP include the reactor core, a typical reheater and steam generator module, a typical hellum circulator and circulator turbine and the turbine generator plant. The major plant control systems are also modeled.

Normal operational transients which can be anaiyzed with ORTAP include reactor start-up and shutdown, normal and rapid load changes. Upset transients which can be analyzed with ORTAP Include reactor trip, turbine trip and sudden reduction in feedwater flow. ORTAP has also been used to fredict plant response to emergency or Saulted conditions such as primary system depressurization, loss of primary coolant flow and uncontrolled removal of control poison from the reactor core. ORTAP predictions will be compared with dynamic test results obtained from the Fort St. Vrain reactor owned by Public Service of Colorado, and based on these comparisons, approprtate improvements will be made in the code. 


\section{NOEIENCLATURE}

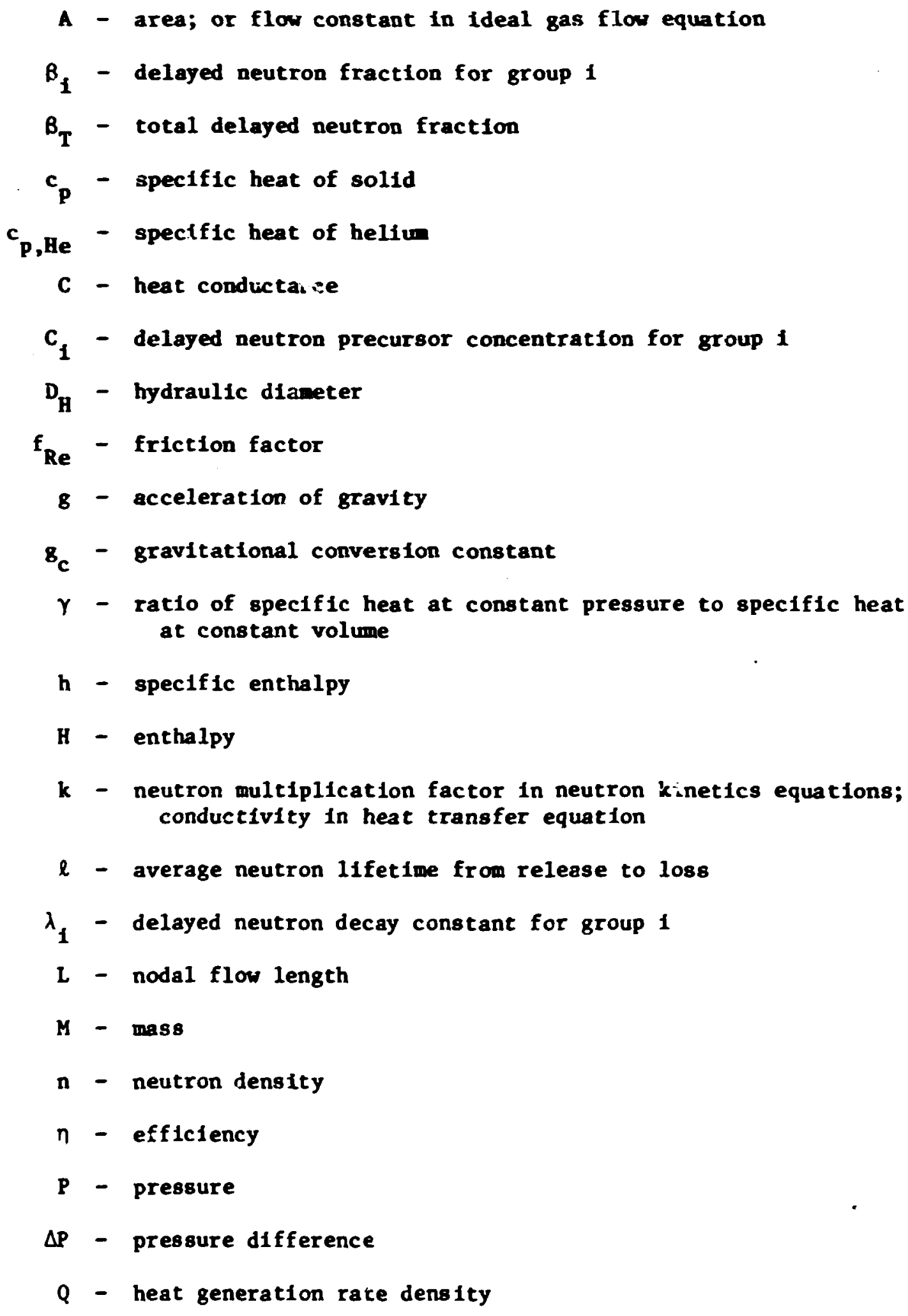




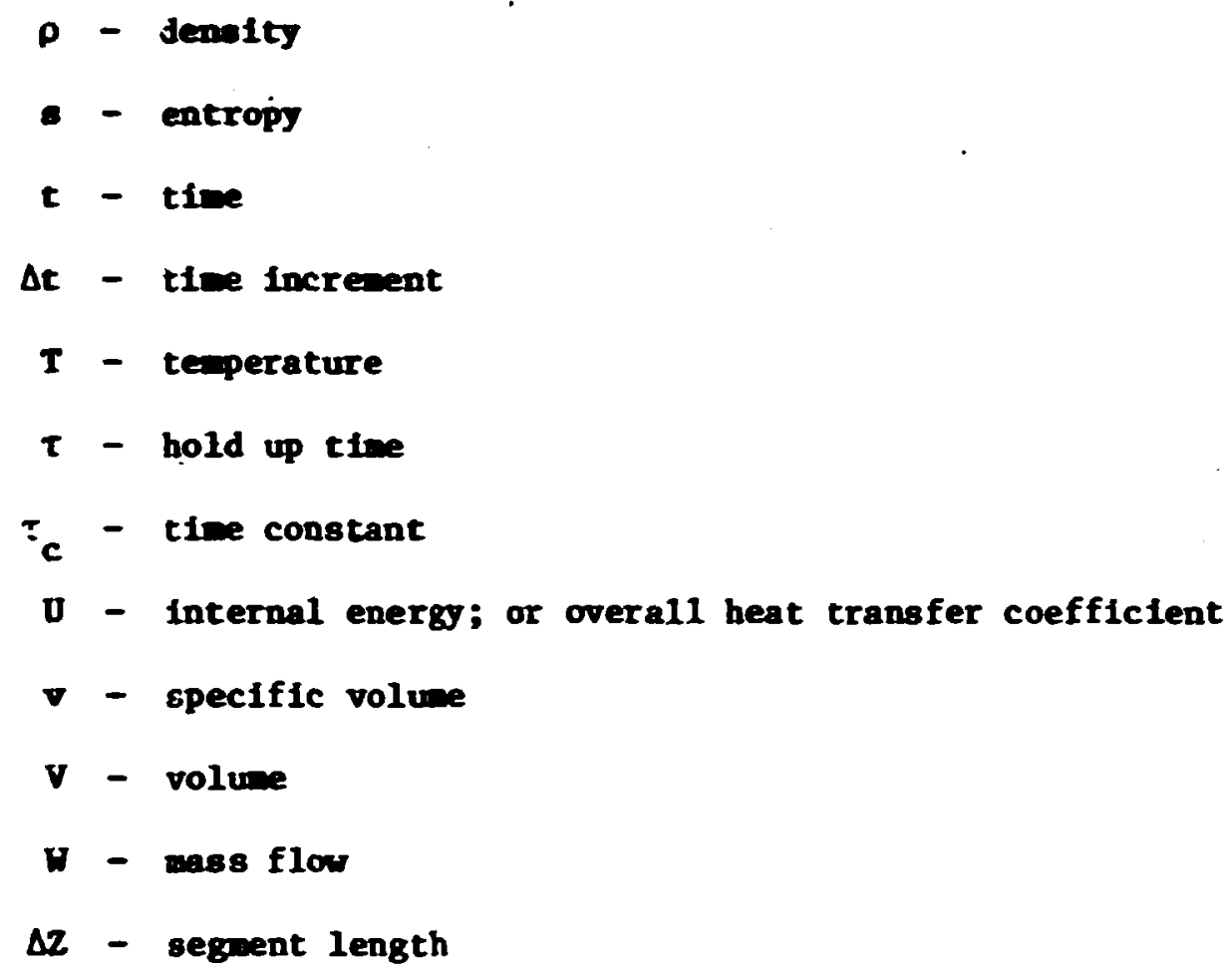




\section{INTRODUCTION}

ORTAP was developed as an Independent method of predicting the dymanic response of the HTGR nuclear steam supply system to a wide range of conditions. The General Atomic Company uses the proprietary TAP ${ }^{1}$ code to predict HTGR transient response. ORTAP contains coupled component simulations of the core $\left(\operatorname{CORTAP}^{2} \mathrm{ORECA}^{3}\right)$; the reheater and steam generator (BLAST ${ }^{4}$ ); the helium circulator and circulator turbine; the high, intermediate, and low pressure turbines; the feedwater heaters; the turbine bypass system; desuperheater and flash tank. ${ }^{5}$ The major plant contrcl systers are also modeled.6

The core is normally simulated by a single-channel model (CORTAP) which couples the heat transfer equations for the fuel, the graphite moderator and the helium coolant with the neutron kinetics equaticns. The core model includes nonlirear effects introduced by temperature dependent fuel, moderator and coolant properties. An alternate core model (ORECA) is used for transients involving low-power and flow cases for which a single-channel model is inadequate. This model includes three-dimensional temperature.distribution calculations, accoints for the varying flow distribuction among the individual refueling regions and accomnodates flow reversals.

The reheater and steam generator are simulated with the multi-node, fixed boundary homogeneous flow model (BLAST). The time dependent conservation of energy, mass and momentum equations for both the hellum side and the water/steam side are solved by an implicit integration te:hnique. Transients involving both start-up and flcod-out of the steim fenerator can be simulated. 
A detailed codel of the turbine generator plant is necessary is: order to accurately predict prinary system component response because of the close coupling between the primary system and the secondary systen. These systems are coupled by heat-transfer in the reheater and stean generator. Also, the exhaust stean from the high pressure turbine drives the heliue circulator turbine before entering the reheater. Additfonal coupling is introduced by the plant control loops. The turbine generator wodel determines pressures, enthalples and flows at several points, including extraction and exhaust ines in the high, fntermediate, and low pressure turbines. The dynamic response of earh feedwater heater and the deaerator is explicitly treated in the model.

As has been indicated above, the circulator turbine is a critical link between the steam and hallum systems in an HTGR. This is especlally true during emergency shutdown and accident transients in which the ever-dwindling nuclear s:sam production provides the power to circulate the primary coolant for afterheat removal. The circulatorturbine model includes calculations of the steam side tirbine pressures, flows and enthalples and the helium circulator side pressure rise, flow and temperature rise. The turbine speed and pressure ratio controls are included.

lollowing turbine trip, steam to drive the circulator-turbine $1 \mathrm{~s}$ provided by the main steam bypass s\%utem which includes a desuperheater and a flash tank. The dynamic response of these components is included in ortap. 
This report contains a description of the HTGR nuclear steam supply (NSS) system and the modeling techniques used in the system simulation. The version of ORTAP described here is for the Fort $S t$. Vrain plant. ORTAP can be used to simulate other HTGRs with changes In Input and anor programing nodifications. A sample t.ansient, input instructions and a sample input listing are included. A deck and listing of the code are available upon request.

\section{DESCRIPTION OF THE HTGR NUCLEAR STEAM SUPPLY SYSTEM}

The Fort St. Vrain (FSV) nuclear steam supply system flow diagram is shown in Fig. 2.1. More detalled diagrams of the core, the reheateronce through steam generator module and the helium circulator are given fn Figs. 2.2 through 2.6. There are two primary coolant loops in the FSV plant. Each primary coolant loop contains six identical reheatersteam generator modules acting in parallel and two helium circulators, also acting in parallel. The core, reheater-steam generator modules, and the hellum circulators are contained in the prestressed concrete reactor vessel (PCRV). Helfum coolant at $\sim 4.83 \mathrm{MPa}(700 \mathrm{psi})$ flows downward in the core through coolant channels in the graphite moderator exiting the core at $\sim 777^{\circ} \mathrm{C}\left(1430^{\circ} \mathrm{F}\right)$. The hot hellum then flows downard through ducts and across helically colled tubes in the reheater-steam generator modules decreasing the hellum temperature to $\sim 404^{\circ} \mathrm{C}\left(760^{\circ} \mathrm{F}\right)$. Except for the superheater II section of the main, stean generator (FIg. 2.5), the reheater and steam generators are counterflow heat exchangers w th the water/steam flowing in the upward direction. After exiting from the economizer end of the steam generator, the helium passes 


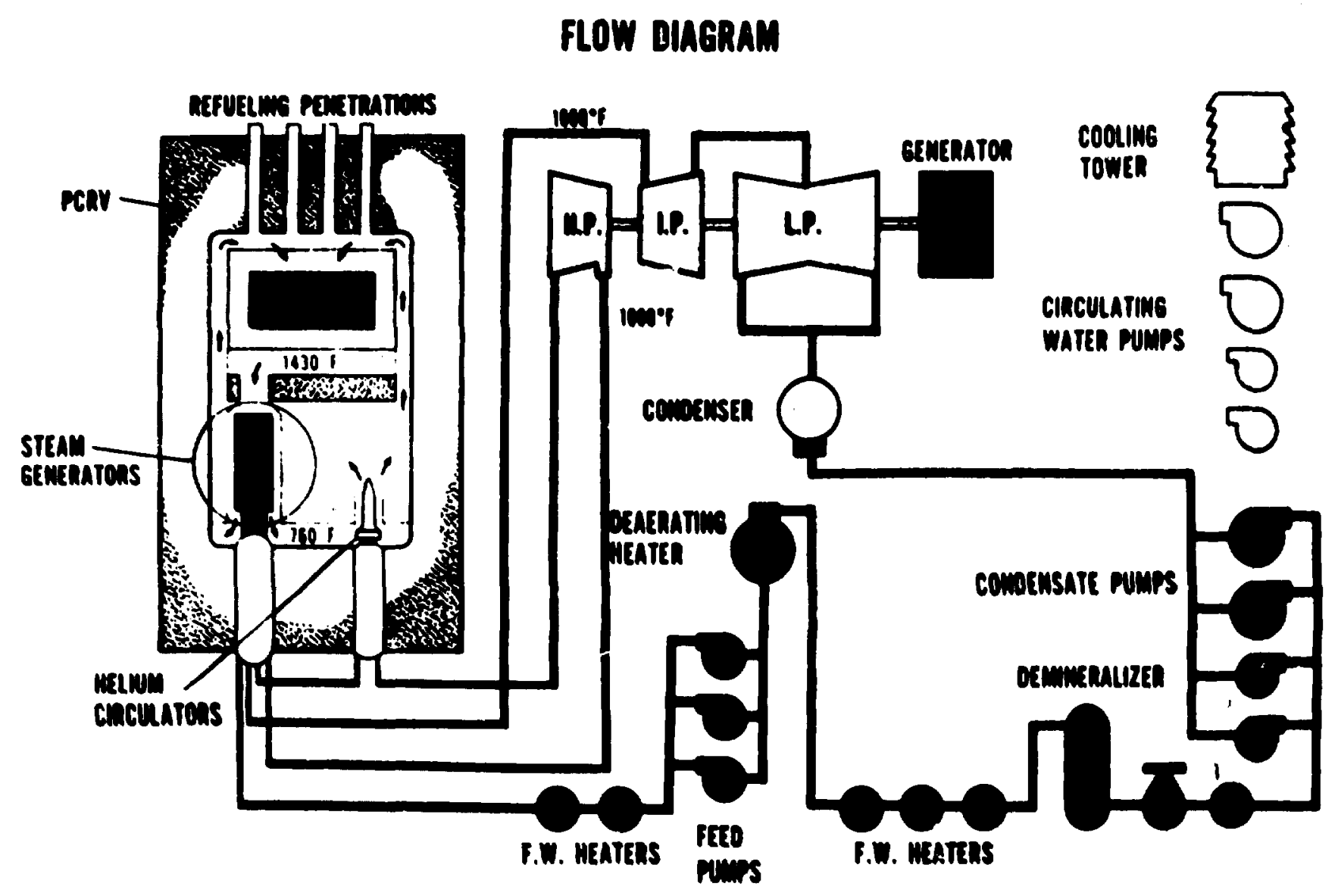

F18. 2.1. Flow diagram of the Fort St. Vraln Reactor. 
ORNL-DIIG 7i-1013IR

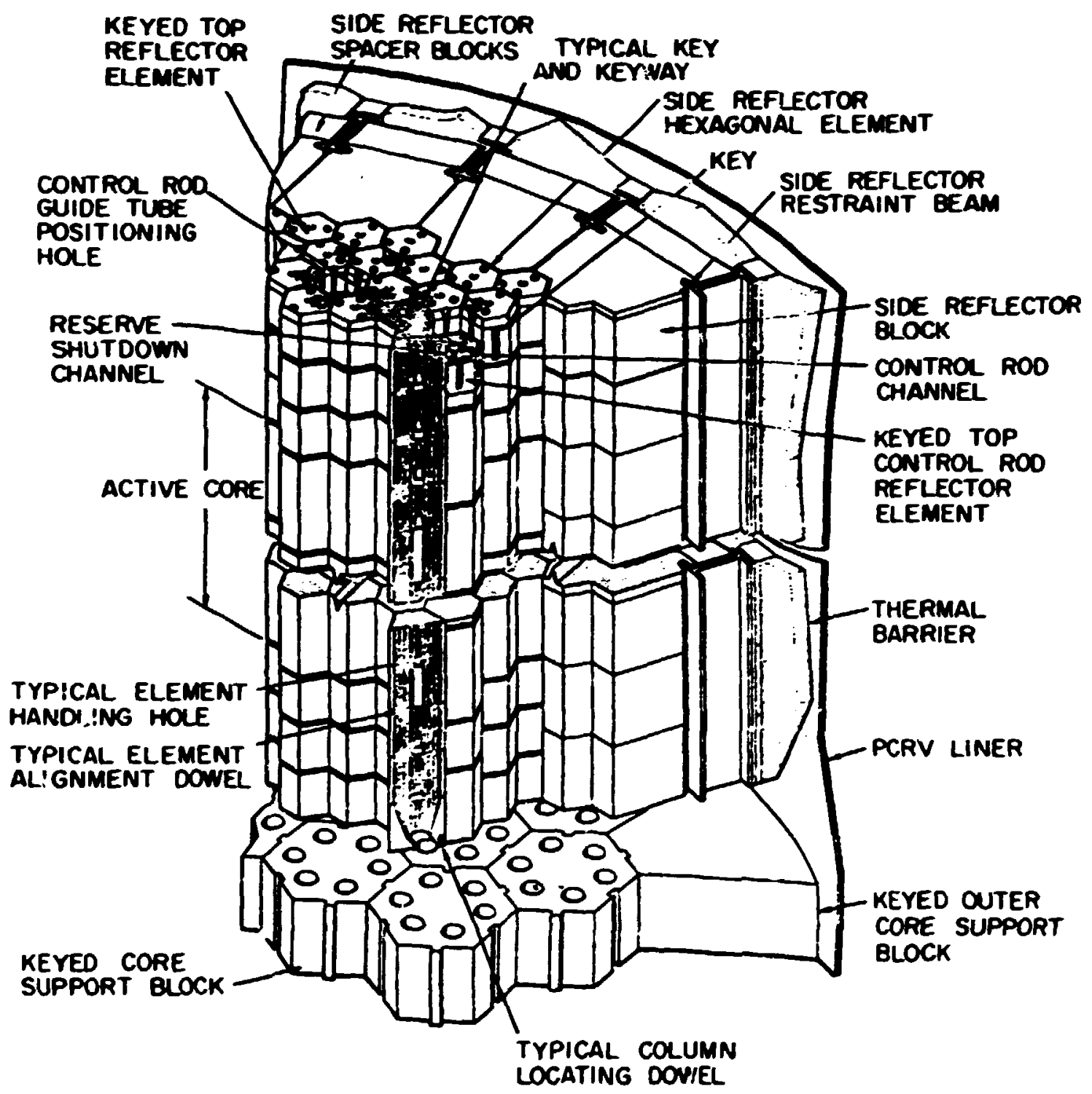

Fig. 2.2. Core element arrangement for the Fort St. Vrain Reactor. 


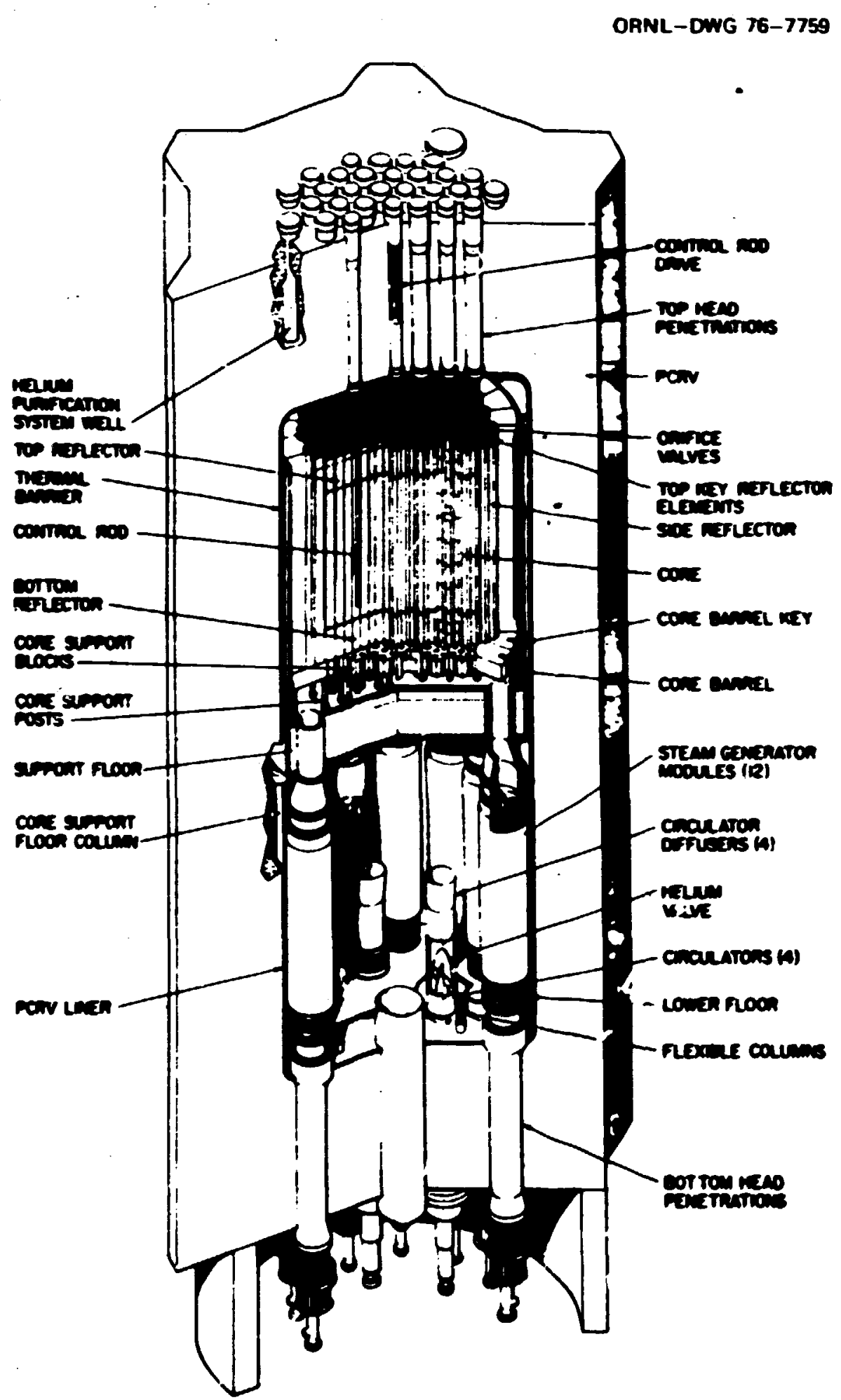

Fig. 2.3. Nuclear steam supply system component arrangement. 


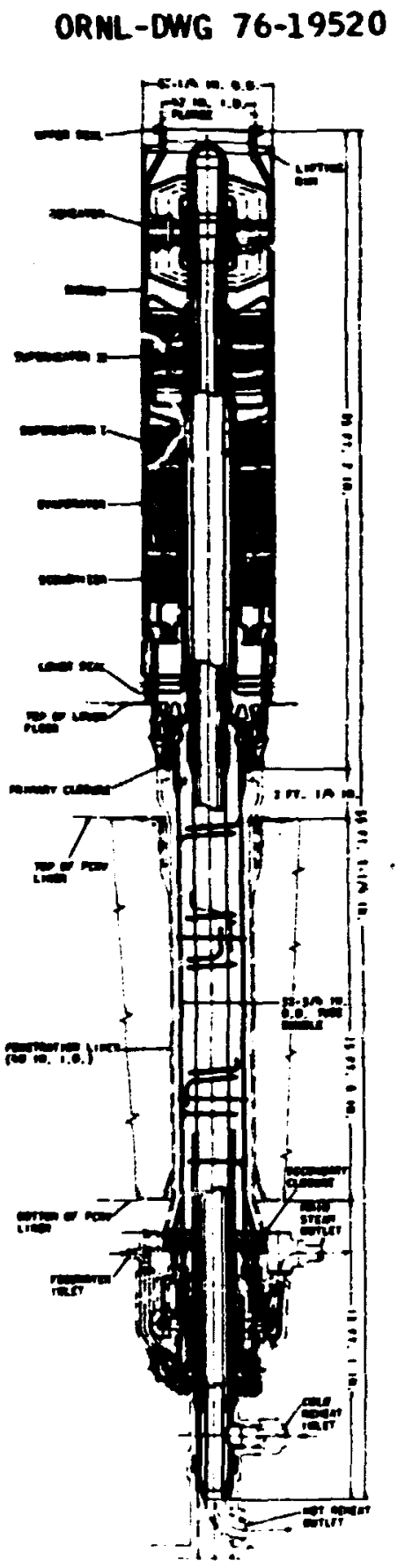

Fig. 2.4. Fort St. Vrain steam generator module. 
ORNL-DWG 76-19518

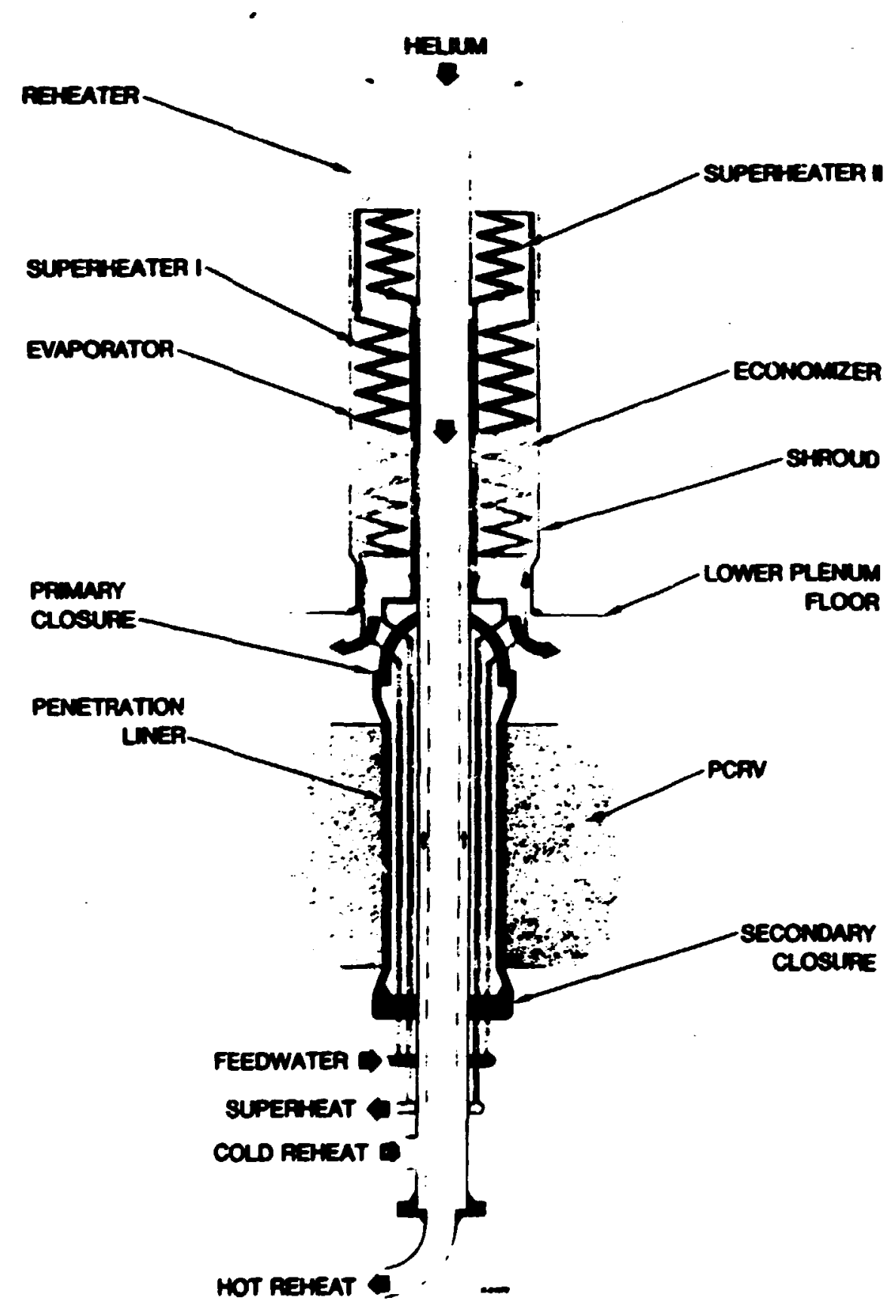

F1g. 2.5. Steam generator schematic. 
ORNL-D:VG 76-19519

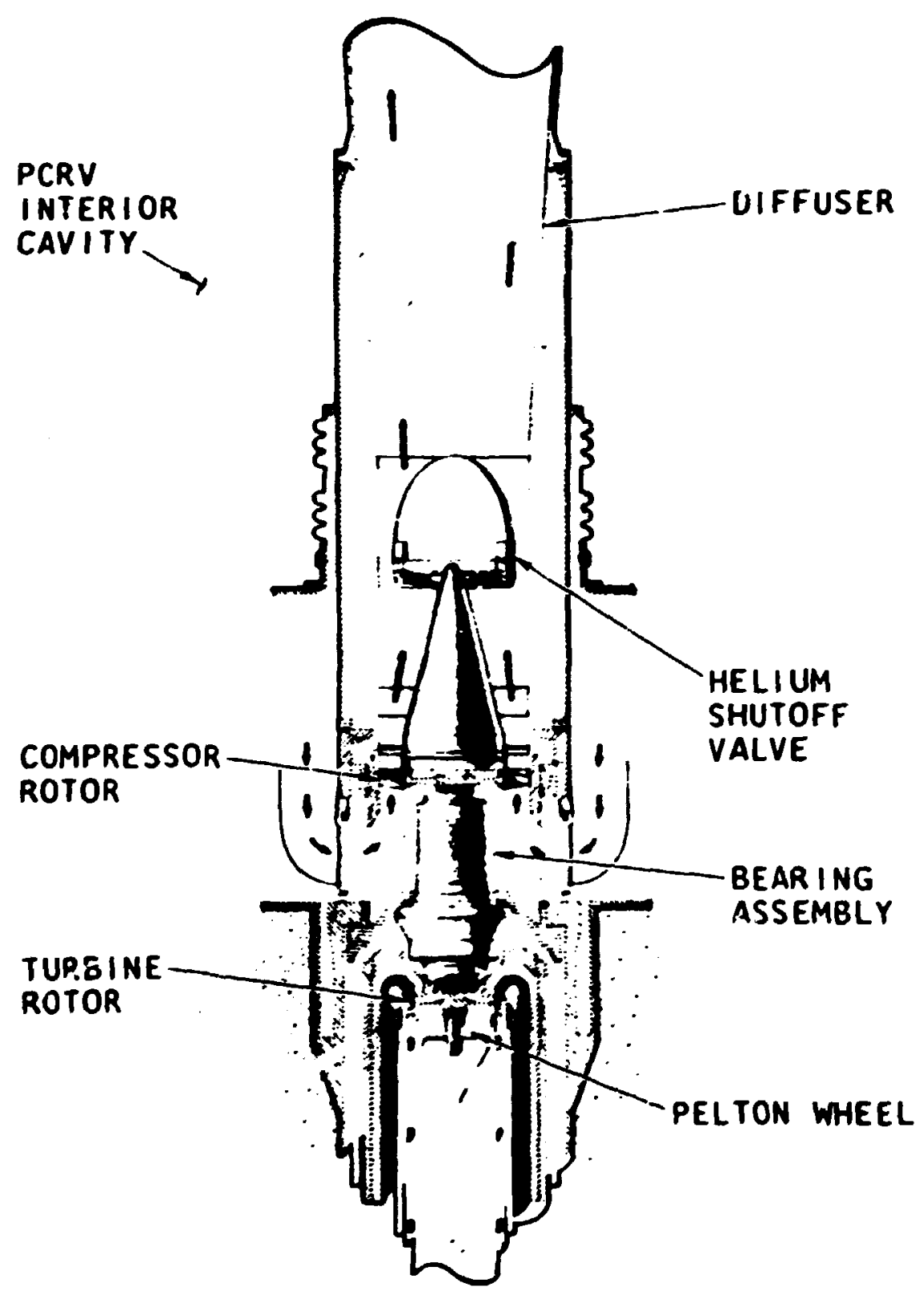

Fig. 2.6. Fort St. Vrain hellum circulator. 
through a plenw to the helfin cfrculator (FIg, 2.6) and then returns to the upper core plenun.

The feedwater flows upvard through the helically coiled tubes in the econonizer-evaporator-superheater I sections of the steam generator and then flows dowmard through the superheater II section. The aln stean condition at the stop valves of the turbine generator unit is $-538^{\circ} \mathrm{C}\left(1000^{\circ} \mathrm{F}\right)$ and $16.55 \mathrm{MPa}(2400 \mathrm{psi})$. As can be seen in F18. 2.1, the main steam first drives the high pressure turbine and then the hellum circulator turbine. After passing through the circulator turbine, th. steam 18 reheated to $-538^{\circ} \mathrm{C}\left(1000^{\circ} \mathrm{F}\right)$ at $6.14 \mathrm{MPa}$ (890 psi). It then drives the intermediate and low pressure turbines (Fig. 2.1) before passing to the condenser. There are various extraction points (not shown in F18. 2.1) from the intermediate and Iow pressure turbines which supply steam to the shell sides of the fecdwater heaters, two turbine driven boller feedpumps and the deaerator.

The stear generators are also used for decay heat removal following reactor shutdown. At these conditions the evaporator and superheater flood, and the superheater discharges heated water to a flash tank.

The main steam bypass system operates whenever the pressure in the steam line to the high pressire turbine exceeds preset limits, (e.g., after a turbine trip). For pressures above $17.68 \mathrm{MPa}(2564 \mathrm{psia})$, the main steam is diverted through a desuperheater to a flash tank, and the steam from the flash tank is then used to drive the circulator turbines. Flow through the desuperheater is limited (due to a limited supply of desuperheat Ing water), 80 any excess steam 18 discharged to the atmosphere whenever the line pressure exceeds $19.06 \mathrm{MPa}$ (2764 psia). After 
a turbine trip, the reheat steam is also bypassed, via a desuperheater, to the an condenser.

\section{CORPONENT SIMLLAETON}

\subsection{Core Kodels}

The Fort St. Vrain reactor core ts shoin in Figs. 2.2 and 2.3. A detailed description of the HTGR fuel element is given in Figa. 3.1.1 and 3.1.2. The FSV core design is quite sibilar to the large HTGR core design. Each hexagonal elewent (Fig. 3.1.1) is $-35.6 \mathrm{~cm}$ (14 in.) acro:s the flats and $-78.7 \mathrm{~cm}$ (31 in.) high. These blocks consist of fuel sticks which corcain bonded coated fuel particles, graphite moderator, and coolant channels. Irifing reactor operation helium flows dowward through the channels. A stack of six layers of fuel elemerts with seven hexagonal fuei elements in each layer is referred to as a refueling region. The central hexagonal element in each layer is a control rod element (Fig. 3.1.2) which contains two control rod rhannels and a channel for the reserve shutdown spheres. Reflector elements are located both above and below each active fuel column as well as around the ctrcumference of the active core. The core is supported on support blocks (F1g. 3.1.3) which rest on core support posts located in the lower core pienum.

The refereace core model which is used in ORTAP is CORTAP, ${ }^{2}$ a coupled neutron kinetics-heat transfer core simulation. The reader is referred to Ref. 2 for the detalls of the modeling techniques used in CORTAP. The core inlet flow rate ard temperature are required as Inputs. CORTAP determines the dynamic response of the core by coupling 


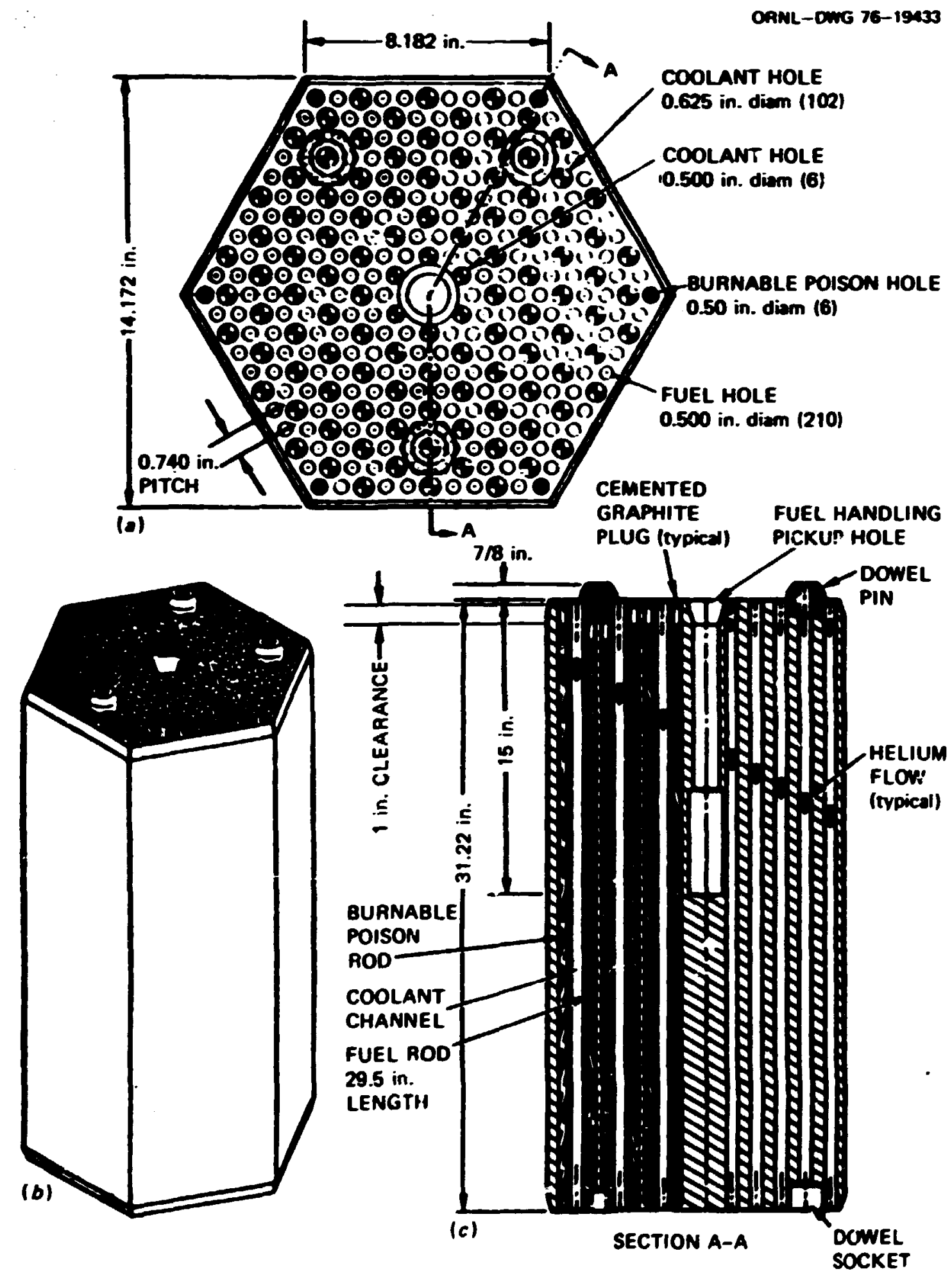

F1g. 3.1.1. Typ1cal HTGR fuel elenent. 


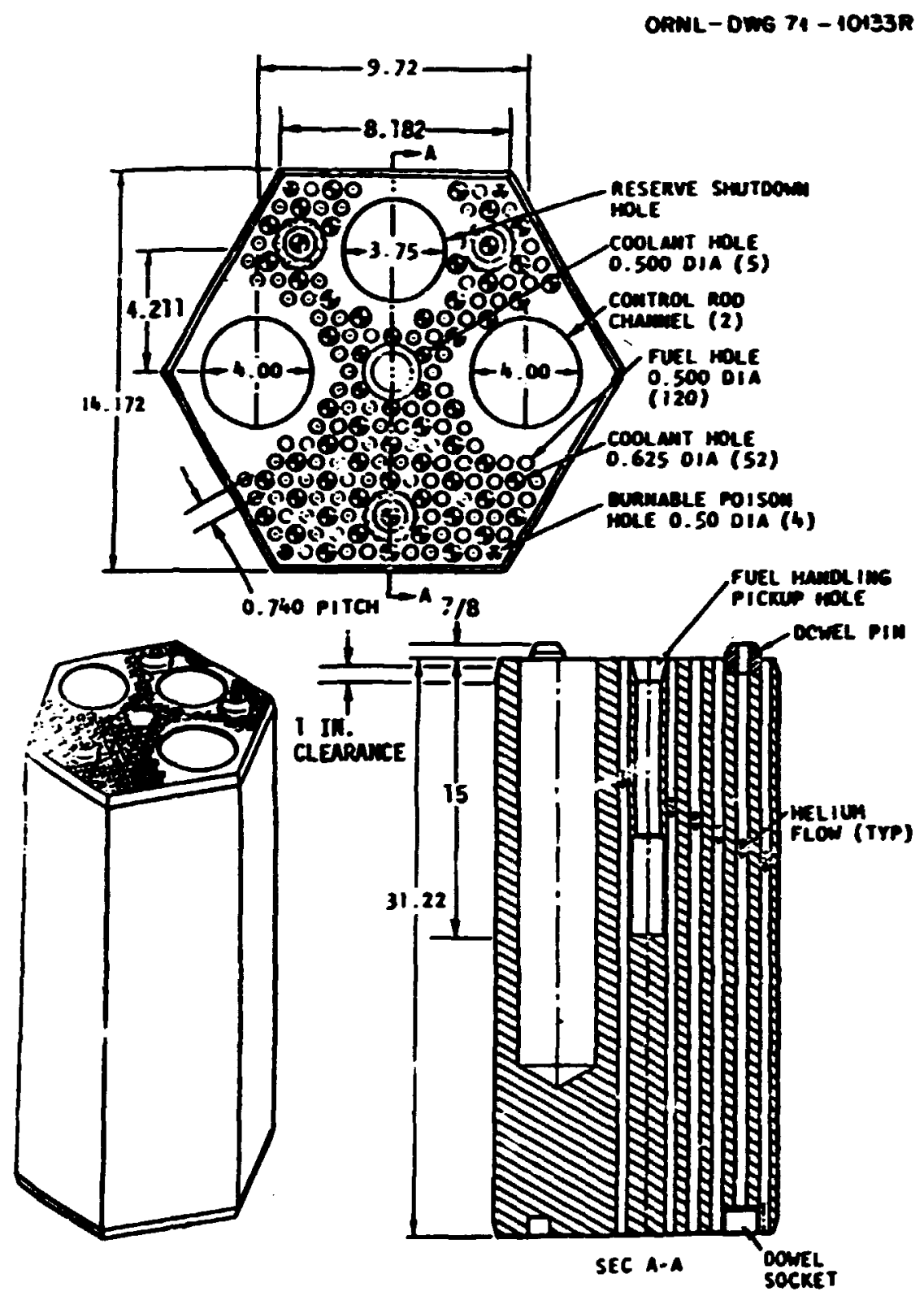

Fig. 3.1.2. HTGR fuel element, showing holes for control rods. 


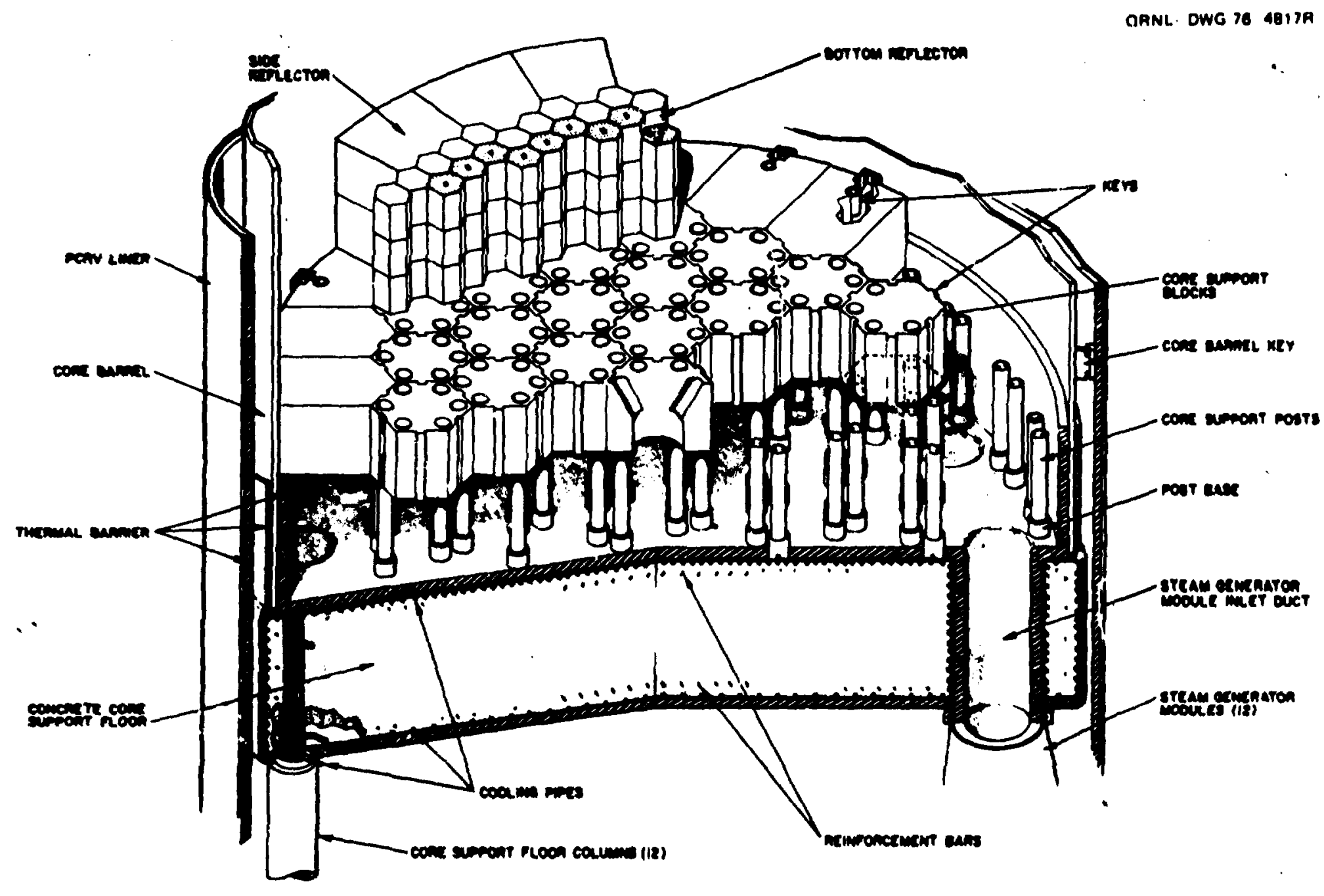

F18. 3.1.3. Lower plenum arrangement. 
the space independent neutron kinetics equations,

$$
\frac{d C_{1}}{d t}=-\lambda_{1} C_{1}+\frac{n k}{l} B_{1}, 1=1, \ldots, 6
$$

and

$$
\frac{d n}{d t}=\frac{n}{l}\left[k\left(1-B_{T}\right)-1\right]+\sum_{1=1}^{6} \lambda_{1} C_{1} \text {, }
$$

wth the equation for heat transfer in the fuel and graphite,

$$
\nabla \cdot(k \nabla T)+Q=\frac{\partial}{\partial t}\left(\rho c_{p} T\right)
$$

and the equation for heat transfer to the coolant,

$$
W c_{\mathrm{P}, \mathrm{He}} \frac{\mathrm{dT}}{\mathrm{gas}} \mathrm{dz}=\frac{\mathrm{C}}{\Delta z}\left(\mathrm{~T}_{\text {wall }}-\mathrm{T}_{\text {gas }}\right) \text {, }
$$

for an average power region of the reactor core. These equations are solved by the matrix exponential technique as described in Ref. 7. CORTAP also has the capability to determire conservative values of fuel, moderator and coolant temperatises in the highest power fuel region by using time-dependent core power, flow, and inlet temperature calculated by ORTAP as forcing functions.

For transients Involving a reactor trip, the core heat generation rate is determined from an expression for decay heat following a scram. Nonlinear effects introduced by temperature dependent fuel, moderator and coolant properties are Included in the model. CORTAP also models the heat transfer in the side reflector and in the core support blocks 
and combines outlet gas temperatures fron the reflector and the support blocks to obtain a wxed sean core outlet gas teaperature.

For transients involving low core coolant flow rates, the singlechamel wodel used in CORTAP may no longer be adequate, since the distribution of flow between regions can change markedly. There are even Instances in which the bouyancy forces cause reverse (upward) flow In some channels. For lou-flow regines, then, the ORECA ${ }^{3}$ core model is subst1tuted for the CORTAP model. For detalls of the ORECA code, the reader is referred to ref. 3. Like CORTAP, ORECA also requires total flow and upper plenun coolant inlet temerature vo t.ine as inputs. In addition, core power is an input function since reactivity fesdback effects are not considered is ORECA.

The major features of the ORECA core model for FSY are as follows:

1. Each of the $3 i$ refueling regions and 18 side reflector blocks 18 represented by eight axial nodes (a total of 440 nodes for the core simulation). Of each group of elght axial nodes, six represent the active core, one the top reflector, and one the bottom reflector and core support blocks.

2. Coolant heat transfer coefficients include the erfects of changing flow regimes (turbulent-transition-laminar) and of hellum conductivity and viscosity varlations with temperature.

3. Input values of axial and radial power peaking factors are assumed constant thron:gisout the run.

4. The flow calculated for each channel is dependent on friction losses, acceleration 108ses, buoyancy effects, entrance/exit 108ses, and orifice pressure drops. Friction losses are dependent on the flow regime. 
5. Grannel flows are calculated at each time step by an iterative scheme that determines the overall core pressure drop which will produce the input total flow rate. Reverse channel flows are also accomodated.

6. Composite core and graphite reflector conductivities and specific heats are calculated as functions of temperature.

\subsection{Reheater-Steam Generator Model}

Each of the 12 identical steam generator modules in the Fort St. Vrain plant is composed of a reheater and a in steam bundle as shown schematically in Fig. 2.5. The once through heat exchanger bundles consist of multistart colls wound in a helfcal arrangement. The water/steam flow is through the helically colled tubes over which the hellum gas flows.

The reheater-steam generator model which is used in ORTAP is BLAST," a mult1-node, fixed boundary, homogeneous flow, single average tube model. The reader is referred to ref. 4 for details of the modeling techniques used in BLAST. On the helium side, BLAST requires as input the Inlet helium flow and enthalpy to the reheater secrion and the helium pressure at the outlet of the steam generator module. Gn the water/steam side the code requires as input the inlet flow and enthalpy and outlet pressure for both the reheater and the main steam bundle.

BLAST solves the nodal form of the time dependent cr.arvation of energy, mass and momentum equations on both the hellum a se water/ 8team sides: 
Conservation of energy:

$$
\frac{d U}{d t}=b_{1 n} W_{1 n}-h_{\text {out }} W_{\text {ont }}+C\left(T_{\text {tube }}-T_{\text {f1uid }}\right)
$$

Conservation of mss:

$$
\frac{d M}{d t}=w_{1 n}-w_{\text {out }}
$$

Conservation of nomentun:

$$
\begin{aligned}
& \mathrm{L} \frac{d d}{d t}=144 g_{c} A(\Delta P)-\rho g A(\Delta z)
\end{aligned}
$$

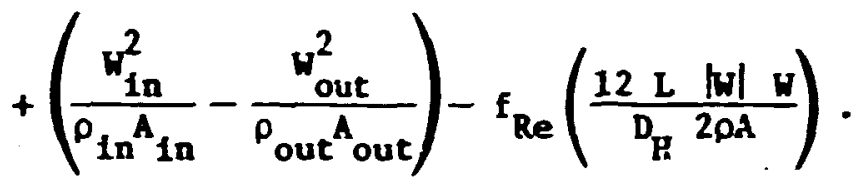

BLAST contains friction factor correlations for both helfum and water and correlations for heat transfer on the helium side and for the various two phase flow regines on the water/steam side. The solution of Eas. (3.5), (3.6), and (3.7) is obtained by an implicit integration technique and yieijs helfum and water temperature, pressure, flow rate and tube wall and bulk temperatures at various points in a reheatersteam generator module during steady-state or transient conditions. BLAST is not ifmited to a spectfic HTGR ateam generator design and can be used to simulate different designs with appropriate input description. The number of nodes used to simulate a specific steam generator can be varied depending on the detall desired. Since a more detalled nodal structure is of ten desirable on the water side than on the helium side, the code allows for more than one tube metal node to recelve heat from a given hellum node. BLAST has been used in 
an ERDA program to calculate pressures and tube temperature gradients in sufficient detall for input to stress analyses for transients resulting from a reactor start-up from refueling status and a postulated rapid depressurization accident.

Figure 3.2.1 shows the BLAST nodal description used in ORTAP to simulate a FSV reheater-stean generator module. As can be seen, the water/stean side of the evaporator is represented in nore detail than other portions of the module. This is done because of the large variation in the heat transfer coefficient, which occurs as the flow regime of the two phase water/stean flow changes from nucleate boiling to file bolling.

\subsection{Turbine Generator Plant Model}

A diagram of the Fort St. Vrain turbine generator plant is shown in Fig. 3.3.1. The components which are simulated by the turbine generator plant model are the high, intermediate, and low pressure turbines, the feedwater pump turbine, the high and low pressure feedwater heaters, the deaerator and several steam lines. The helium clrculator, clrculator turbine and the circulator turbine bypass are simulated in a separate model. There is also a model of the high pressure turbine bypass system, the desuperheater and the flash tank which is used in ORTAP following a turbine trip. It is assumed that the feedwater pump provides the feedwater flow requested by the feedwater flow control system with a specified 198 so the feed pump itself is not modeled. The condensate flow in the low pressure feedwater heaters is controlled to maintain a constant deaerator level. 
OANL DWG 77.2722

LENGTH OF

TUBE RE?PESENTED

BY NODE

$2.39 \mathrm{~m}(7.85 \mathrm{ft})$

$2.39 \mathrm{~m}(7.85 \mathrm{ft})$

$15.18 \mathrm{~m}$ (49.81 ft)

REHEAT

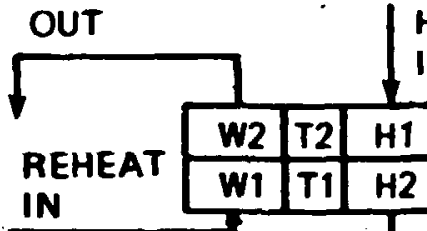

SECTION

OF MODULE

IN

SUPERHEATER II

SUPERHEATER I

EVAPORATO 9 ॥

$3.56 \mathrm{~m}$ (11.69 ft)

$7.78 \mathrm{~m}(25.51 \mathrm{ft})$

$11.70 \mathrm{~m}(38.40 \mathrm{ft})$

$11.70 \mathrm{~m}(38.40 \mathrm{ft})$

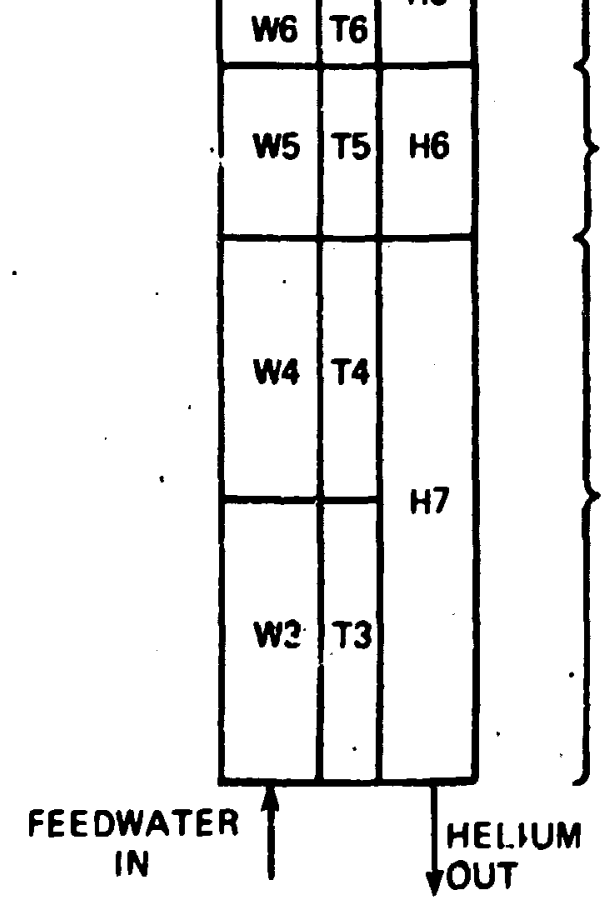

EVAPORATOR I

ECONOMIZER

$W=$ WATER NODE

$T=$ TUBE NODE

$H=$ HELIUM NODE

F18. 3.2.1. Nodal arrangement for BLAST simulation of FSV steam generator. 


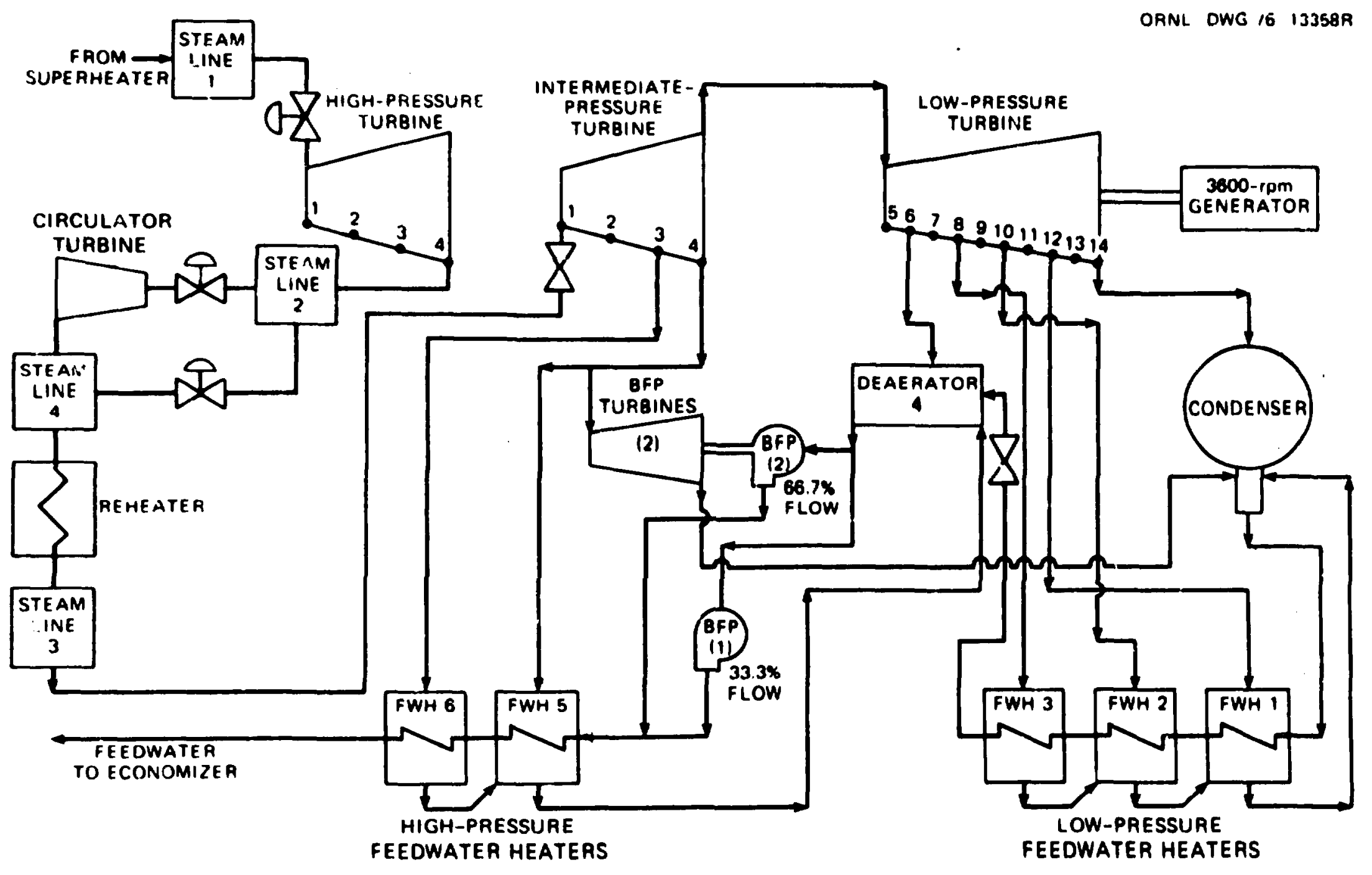

F18. 3.3.1. Fort St. Vrain Reactnr turbine-generator plant flow diagram. 
The turbine generator plant aivilation is a codification of that presented In Ref. 8. The technique used is to isolate each component fron the others during a calculational time step. The mass and heat flow rates between components realn constant during a tine step and are updated afte: each tise step.

In order to establish initial conditions, the simulation requires the following steady-state Informat ion as input:

1. flow rate in each turbine inlet, extraction and exhaust line;

2. pressure and exthalpy at each number turbine location in Fig. 3.3.1;

3. pressure and enthalpy in each stean holdup IIne;

4. pressure at the end of each extraction and exhaust 1ine;

5. drain coolant flow from each feedwater heater and feedwater flow through each feedwater heater;

6. temperature of feedwater entering and leaving each feedwater heater; temperature of l1quid leaving drain cooler and vapor pressure in ezch feedwater heater shell;

7. one set for each feedwater heater:

2. holdup time of feedwacer in drain cooler section, b. drain cooler holdup time, c. holdup time of feedwater in evaporator section, and d. steam holdup time;

8. holdup time of each steam 11ne; and

9. time dependent electrical demand.

The procedures used in simulating the high, intermediate, and low pressure turbines (and feedpump turbine) are essentially the same. It 1s assumed that the rotor speed remalns unchanged, in which case the 
turbine steam conditions respond very. swiftly to perturbations in inlet variables. It is assumed that this reaction time is short comared with the computational time step (usually from 0.1 to $0.5 \mathrm{sec}$ ) so that the turbine is alkays essentially in steady-state.

At $t=0$, the following calculations are performed based on the intial steady-state input information:

1. Calculate flow constants (A's) for each turbine stage, each inlet 1ine, extraction 1ine, and exhaust line from the ideal gas fiow equation:

$$
\left.W=A\left[\frac{\gamma}{\gamma-1}\left(\frac{P_{1}}{v_{1}}\right)\left(\frac{P_{2}}{P_{1}}\right)^{\frac{2}{\gamma}}-\left(\frac{P_{2}}{P_{1}}\right)^{\frac{\gamma+1}{\gamma}}\right]\right\}^{\frac{1}{2}},
$$

where the subscript 1 refers to upstream values, and 2 refers to downstream values.

2. Calculate efficiency $n$ of each turbine stage from input information by the following technique:

$$
\begin{gathered}
s=s\left(P_{I n}, h_{I n}\right), \\
h_{s, \text { out }}=h\left(s, P_{\text {out }}\right),
\end{gathered}
$$

then

$$
\eta=\frac{h_{\text {in }}-h_{\text {out }}}{h_{\text {in }}-h_{\text {s, out }}},
$$


where

$$
\begin{aligned}
& \text { h } \equiv \text { entha1py, (Btu/1bu), } \\
& h_{s, \text { out }} \equiv \text { enthalpy for } 1 s \pm n t r o p i c \text { expansion to } P_{\text {out }} \text { (Btu/1ba), } \\
& \text { s } \equiv \text { entropy, }\left(\text { Btu.'Ibe- }{ }^{\circ} \mathrm{F}\right) \text {, } \\
& P \text { Piessure, (psia). }
\end{aligned}
$$

ORTAP assumes that the efficlency of -3ch turbine stage is constant during transients.

For $t>0$, the flor through the high pressure turbine throttle valve 18 controlled to produce the required electrical power, which may vary wth time according to Input inforsation. The following calculations are performed for the interwediate and low pressure turbines at each time step.

1. From values of P (steam line 3) and pressures at end of extraction and exhaust 11nes, the simulator iterates to solve a pressure-flow balance over each spction of the turbine using the Ideal gas flow equation (3.8). P (steam line 3) and the pressures at the end of extraction and exhaust lines are assumed constant during the time step and updated at the end of the time step.

2. Following calculation of the pressure at the end of each section In the Intermediate and low pressure turbines (FIg. 3.3.1), the steam expansion calculation frovides the enthalpy at the end of each section using the following technique:

$$
\begin{gathered}
h_{1} h(\text { steam line } 3), \\
h_{1+1}=h_{1}-\eta_{1,1+1}\left(h_{1}-h_{8,1+1}\right),
\end{gathered}
$$


where

$$
\begin{aligned}
n_{1,1+1} \equiv & \text { the } \in \text { fficiency of the section between points } 1 \text { and } \\
& 1+1, \\
h_{s, 1+1} \equiv & \text { the enthalpy for an isentropic expansion to } p_{1+1} \\
& \text { and } 1 \text { s obtained from }
\end{aligned}
$$

$$
\begin{gathered}
s=s\left(P_{1}, h_{i}\right), \\
h_{s, 1+1}=h\left(P_{1+1}, s\right) .
\end{gathered}
$$

This calculated enthalpy is then used to determine the specific volume. Following convergence of the flow-pressure balance calculations, the power generated by the intermediate and low pressure turbine is then calculated from $P=\sum W \Delta h$ over each section. The electrical output, $P_{e}$, is determined by $P_{e}=P \eta_{s}$, where $\eta_{s}$ is tive assumed value of the generator shaft efficiency.

3. Next, a pressure-flow iteration is performed for the high pressure turbine, given the pressures in steam 1 ines 1 and 2 , and the electrical output from the high pressure turbine is determined. If the total electrical output from tine high, intermediate, and low pressure turbines differs from the required electrical demand at time the flow constant of the valve upstream of the high pressure turbine is changed. The high pressure turbine calculations are repeated until the power production and the electrical demand crnverge.

Steps 1, 2, and 3 above are repeated for each time step. 
Stean lines 1, 2, 3, and 4 (Fig. 3.3.1) are modeled as "mixing tanks." Fron Input values of stean line flow rate, enthalpy, pressure and holdup tine, the following quantities are calculated at $t=0$ :

$$
\begin{aligned}
& \mathbf{H}=\mathbf{H} \cdot \boldsymbol{\tau} \\
& \mathbf{H}=\mathbf{H} \cdot \mathbf{h} \\
& \mathbf{T}=\mathbf{T}(\mathbf{P}, \mathbf{h}) \\
& \mathbf{V}=\mathbf{V}(\mathbf{T}, \mathbf{P}) \\
& \mathbf{V}=\mathbf{H},
\end{aligned}
$$

where

$$
\begin{aligned}
& M \equiv \text { mass of steam in line }(1 \mathrm{bm}), \\
& H \equiv \text { enthalpy (Btu), } \\
& h \equiv \text { specific enthalpy }(\mathrm{Btu} / 1 \mathrm{bm}), \\
& v \equiv \text { spectifc volume }\left(\mathrm{ft}^{3} / \mathrm{bm}\right), \\
& v \equiv \text { steam line volume }\left(\mathrm{ft}^{3}\right) .
\end{aligned}
$$

For $t>0$, the mass and enthalpy in each steam line is determined from

$$
\begin{gathered}
M !(t+\Delta t)=M(t)+\left(\Sigma W_{\text {In }}-\Sigma W_{\text {out }}\right) \Delta t, \\
H(t+\Delta t)=H(t)+\left(\Sigma W_{\text {In }}^{h}{ }_{\text {in }}-\Sigma W_{\text {out }}{ }^{h}{ }_{\text {out }}\right) \Delta t,
\end{gathered}
$$

where inlet and outlet flow rates and enthalpies are assumed constant during the time step and are updated at the end of each time step.

The pressure in each stean line is then determined from

$$
v(t+\Delta t)=v / M(t+\Delta t)
$$

and 


$$
\mathbf{P}=\mathbf{P}(\mathbf{v}, \mathbf{h}) \text {. }
$$

These pressures are used to compute flows in and out of the steam lines for the next time step using the ideal flow equation.

A diagran of the feedwater heater model used in the curbine generator plant simulation is shown in Fig. 3.3.2. A lumped parameter model using nine differential equations is used to describe each feedwater heater. The model determines the time dependent feedwater exit temperature from each feedwater heater. The simulation used in ORTAP is the same as is used for the feedwater heater simulation in Ref. 8, and the reader is referred to that report for a more detailed description of the modeling technique.

As shown in F1g. 3.3.2, stean from the turbine extraction enters the shell side vapor section of the feedwater heater. If this steam is superheated, it is assumed first to give up this superheat to the exiting feedwater. If the steam is wet, it is divided into a saturated steam part and a saturated liquid part.

Ifquid from a previous feedwater heater may also enter the shell side drain cooler section of the heater. Since its temperature is: usually hotter than the saturated vapor temperature, some of 1 flashes. The vapor goes into the vapor space and combines with the steam from the extraction line. Steam in the vapor space condenses on the tubes containing the feedwater. This liquid eventually flows into the drain cooler section of the feedwater heater. As it flows through the drain cooler, it loses some of its heat to the feedwater.

The feedwater enters the feedwater heater in the tube bundles and flows counter to the direction of the drain coolant flow. After 


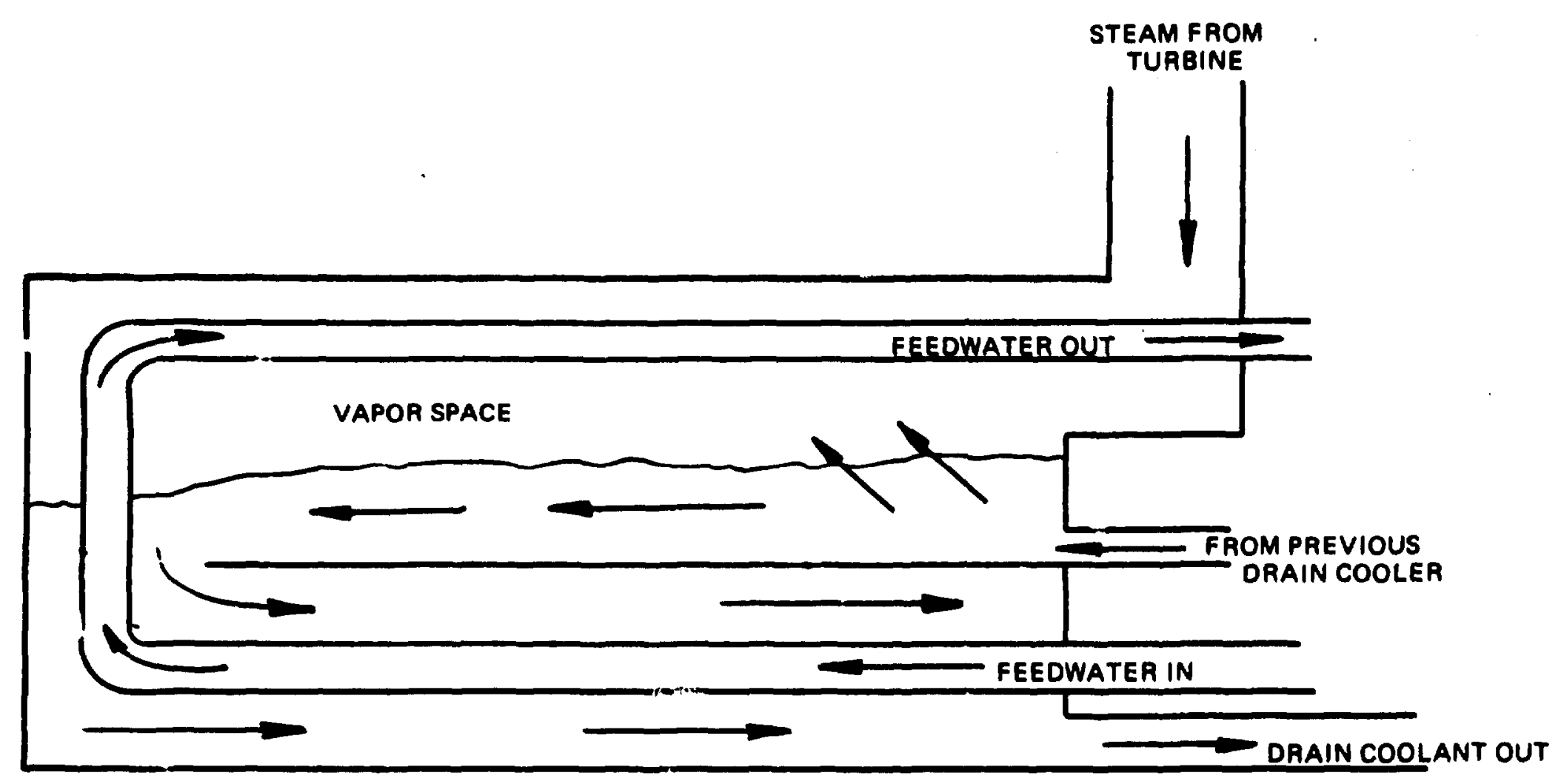

Fi8. 3.3.2. Feedwater heater model. 
leaving the drain cooler section, the feedwater heater enters tube bundles in the vapor space where it heats up some more as sheli side steam is condensed. Before leaving the heater, the feedwater in the tube bundle passes through a superheat section where the superheat in the extraction stean (if any) is removed.

In the simulation, the drain cooler section of the feedwater heater is treated as a tube-in-shell counterflow heat exchanger where the shell side has a uniform (saturated) temperature. The superheated extraction steam section is handled by a simple heat balance.

\section{3.: Helium Circulator and Circulator-Turbine Model}

The circulator-turbine model subroutine (ORCIRT) calculates the steam-turbine side pressures, flows, and enthalpies, as well as the helium-circulator side pressure drop, flow, and temperature rise (Fig. 3.4.1). It also incorporates the turbine speed and pressure ratio control sysiems.

ORCIRT is integrated into the turbine-generator plant routines, using the pressure and enthalpy of the high-pressure turbine exhaust steam and the reheater steam inlet pressure as boundary conditions; each of these is assumed to be constant over the computation time Interval. The desired circulator speed is "requested" by the overall plant average main steam temperature control system. This input request is normally satisfied as long as adequate steam is avallable. However, with the speed control valve wide open and the bypass valve closed, if the turbine power output is insufficient to maintain the requested speed, the speed will droop accordingly. This 18 known as the pressure-1imited mode. Occaslonally, for rapid decreases in 


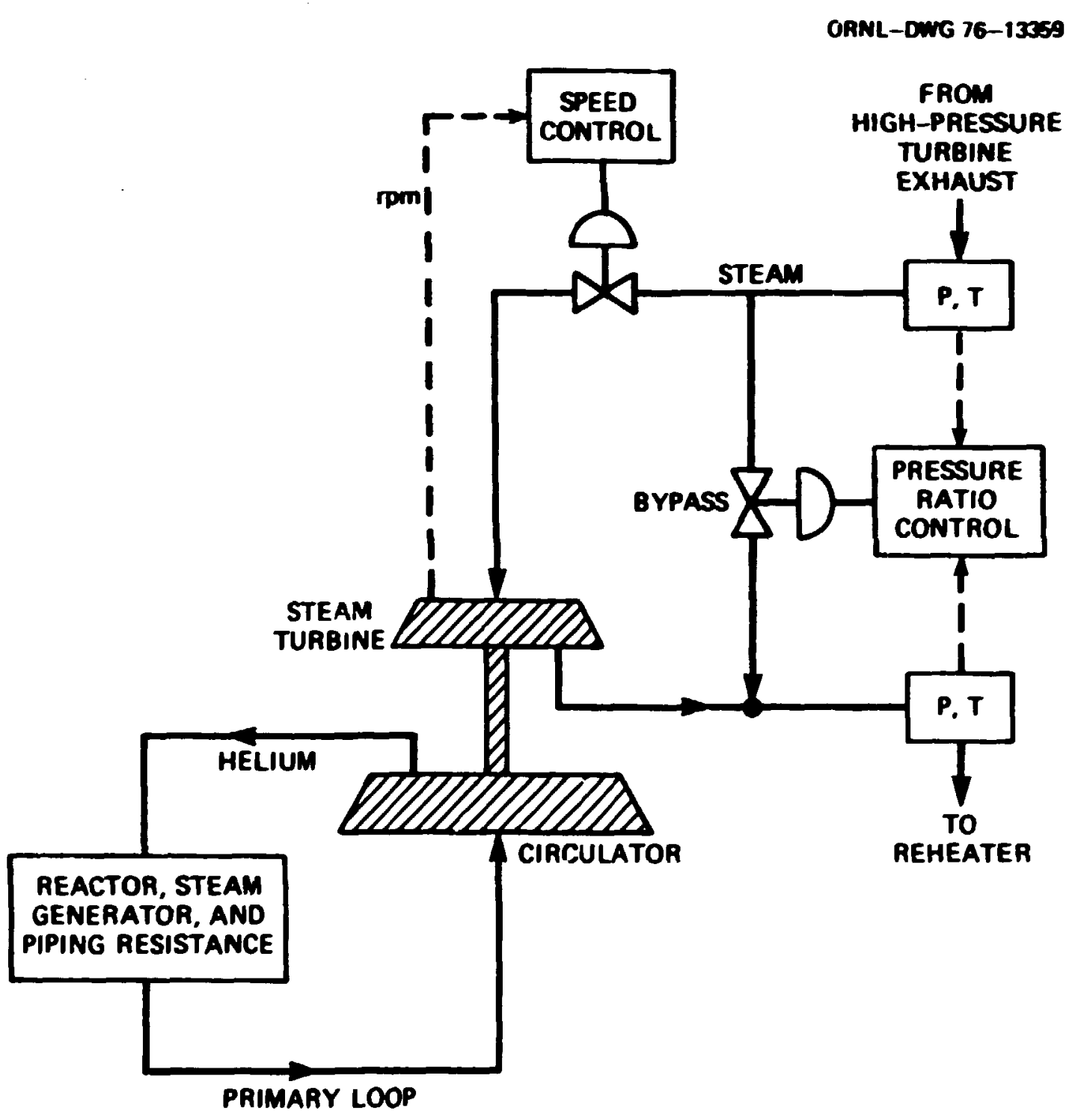

P1g. 3.4.1. Circulator turbine model. 
requested speed, the rotor inertia will make the actual speed exceed the requested speed even with no turbine steam flow. This is the coastdown mode.

The circulacor and turbine characteristics modeled In ORCIRT are derived from empirical data sufolled by GAC In the FSV-FSAR' and the TAP code report, 1 and from personal comunication with GAC.

The circulator performance map for the FSV untts was recast in terms of a normalized pressure rise as a function of normalized flow and then was represented by a quadratic equation, as suggested by LASL. 10 Primary loop flor is calculated explicitly by using a quadratic formulation for the circulator map and assuming that $\Delta \mathrm{P}$ is proportional to flow squared in the primary loop components. The circulator power required for given speed and hellum-side conditions is calculated from a quadratic fit to a GAC-supplied normalized power curve. Other power losses included are due to bearing friction and rotor acceleration.

Once the power requirements have been established for a given rotor speed, the required turbine inlet pressure is determined for an assumed value of turbine steam flow. If this pressure is avallable, a comparison is made between the average specific volume based on inlet/outlet conditions and that required to satisfy the turbine torque map. The assumed value of steam flow is adjusted until the difference in spectfic volume calculations is sufficiently small.

If the avallable pressure is not sufficlent to maintain the requested speed, another iterative loop is used to determine the maximum speed obtainable with the speed control valve wide open and the bypass valve closed. Provisions are made for entering and exiting the pressurelimited mode. 
The turbine efficlency, wth an imposed lower limit, is updated for eaci iteration. Messages are printed out if the turbine is supersonic or has wet exhaust stean, or if the circulator is in the stall region.

A calculation is then ade of the approxinate bypass flow required to mintain a constant pressure rat 10 between the high-pressure turbine exhaust and the circulator-turbine exhaust. Because of the holdup volues at these two points, the calculation cannot be made explicitly; Instead, the bypass flow is adjusted at each time step to correct the pressure ratio to the desired value on a $2-\sec$ time constant.

\subsection{Turbine Bypass, Desuperheater, and Flash Tank Models}

The main steam turbine bypass system, including the desuperheater and flash tank, is shown in Fig. 3.5.1. In the main steam bypass (MSBP) wodel it is assumed that the pressure control systems respond instantaneously compared to other system dynamic responses. Hence the MSBP valve opens whenever the main steam pressure exceeds $17.68 \mathrm{MPa}$ (2564 psia) and attempts to maintain that pressure. The flow through the MSBP valve is assumed to have a spectfied upper limit. Any flow in excess of this limit causes the pressure to build up until it reaches a second upper limft of $19.06 \mathrm{MPa}$ (2764 psia). At that point, the vent valve opens and allows enough steam to escape to the atmosphere to maintain that pressure.

In the model for steam temperature control at the desuperheater outlet, it 18 assumed that there are no pressure drops in the lines between the desuperheater outlet, the flash tank, and the high-pressure turbine outlet; $1 . e .$, it is all at the pressure of the node designated 


\section{MORMAL OPERATION OF SECONDARY COOLANT SYSTEM}

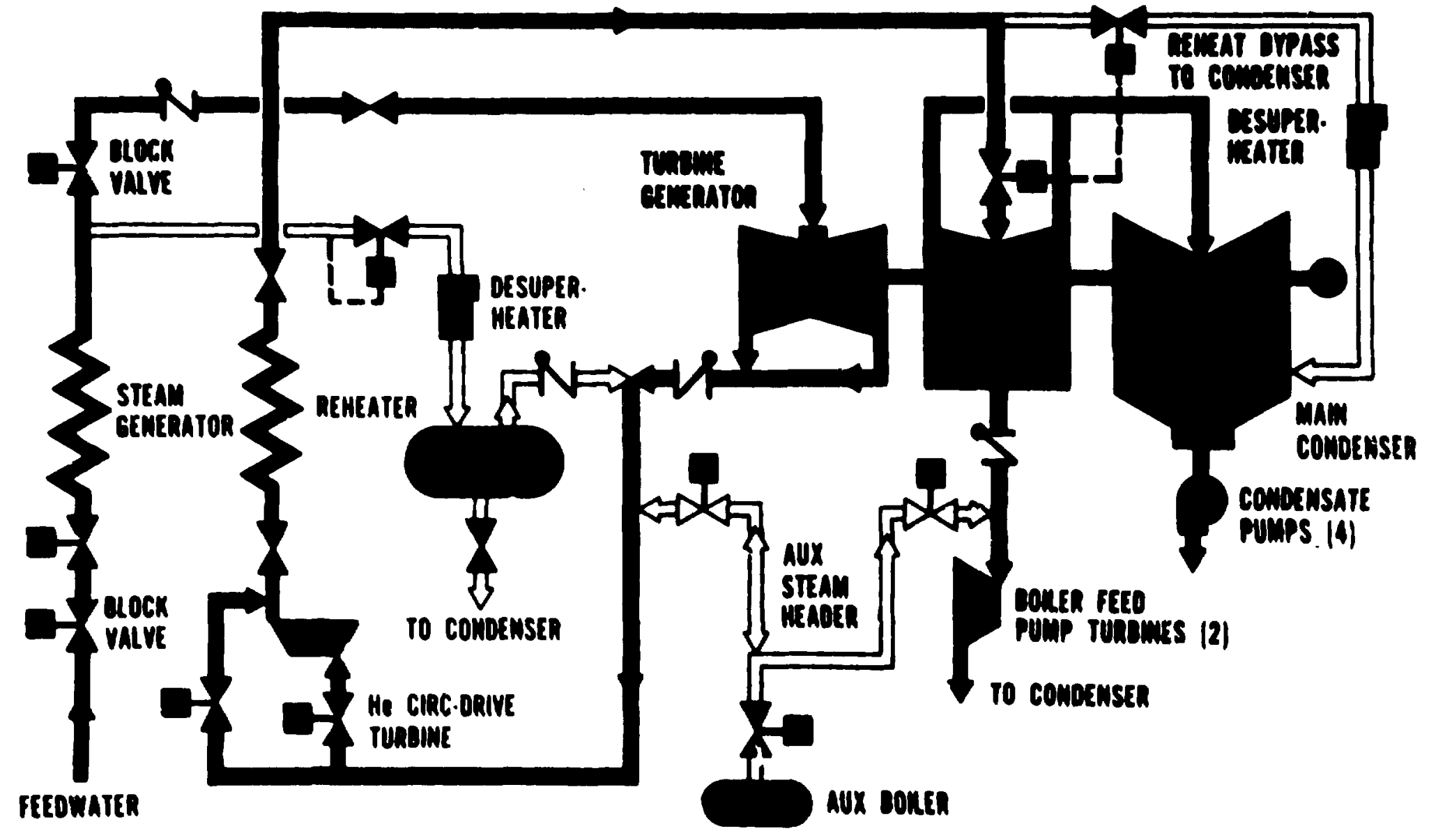

F1g. 3.5.1. Turbine bypass syatems. 
as "steam line 2" In Fig. 3.3.1. Given this pressure and the set point temperature, the corresponding enthalpy "set point" for the desuperheater exit steam can be found. From this it can be determined how wch desuperheating water must be added to the bypass stean to reduce 1t wi: the set point temperature. The phase of the fluid to the flash tank is also calculated, and only superheated or dry steam is assumed to flow to the circulator turbine. Any liquid is returned to the condenser hot well.

\section{CONTROL SYSTEM SIMULATION}

Three overall plart control loops are simulated in ORTAP. The controlled variable, dependent variable and feed-forvard variable for each loop are given below.

\section{Controlled Variable}

MaIn steam temperature

High pressure turb ie throttle pressure

Reheat steam temperature Reactor power
Dependent Vartable

Helium circulator speed

Feedwater flow
Feed-Forward Variable

Feedwater f1ow

High pressure turbine first stage pressure

High pressure turbine first stage pressure

Figure 4.1 is a block diagram showing the typical relationshtp between the controlled, dependent, and feed-forward variables, using the main steam temperature controller as an example. The feed-forward varlabie 18 used to enhance the response to load changes and is added directly to the controller output signal as shown in F1g. 4.1. The model for the controller slıows the set point signal entering downstream 
ORNL-DWG 77-2723

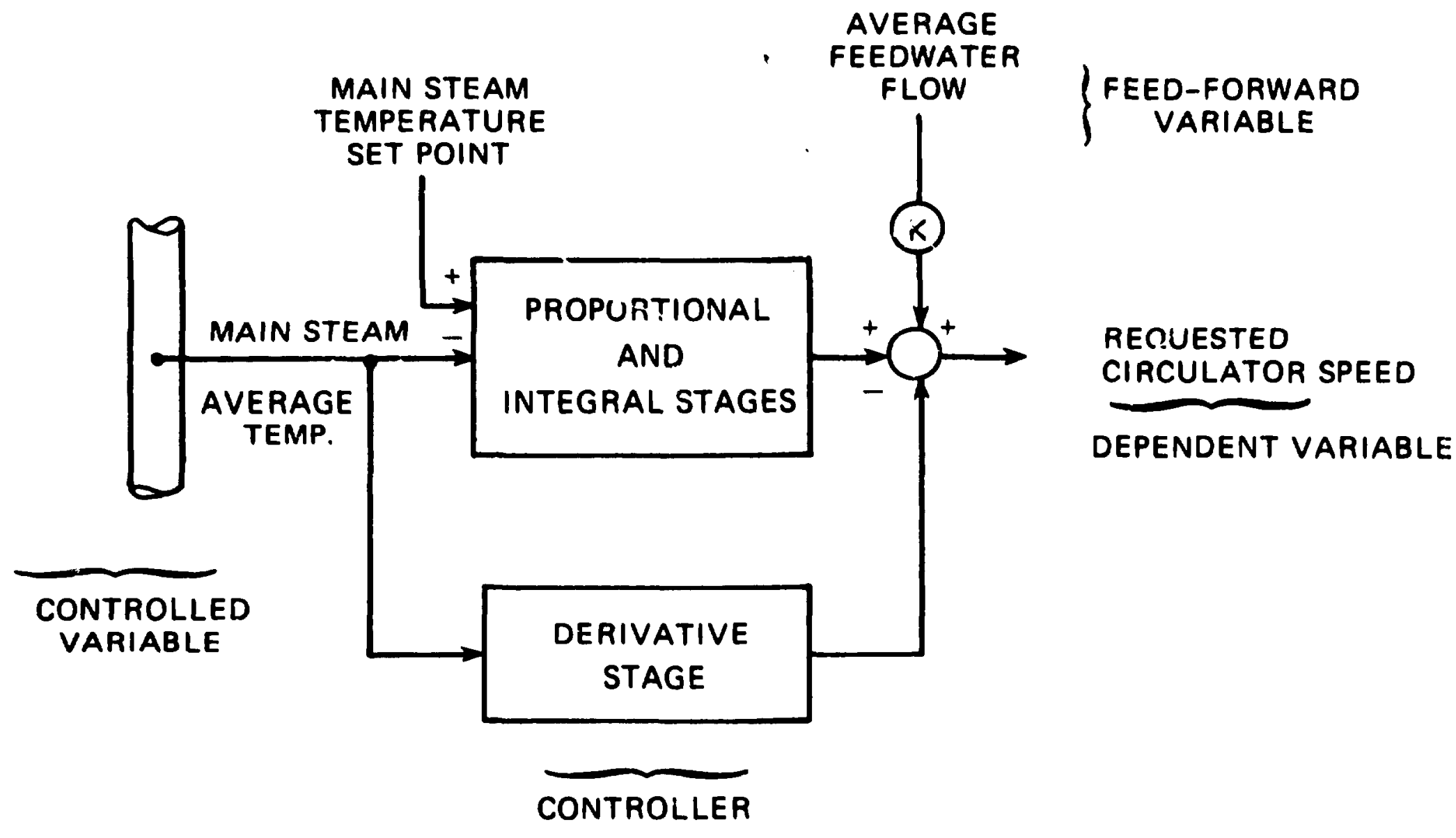

F18. 4.1. Typ1cal control system modu:. 
of the signal to the derfuative stage, as in the Foxboro Spec. 200 electronic controllers used at FSV. This elfminates spurfous system responses to rapld set point changes. The model also includes both integral (or reset) gain and derivative gain 1 imits of 100 and 10 , respectively.

\section{COUPLING OF COMPONENT MODELS IN THE SYSTEM SIMULATION}

ORTAP was developed by coupling the individual component simulatfons with the plant control systems. It is assumed that the helium flow, as calculated by the helium circulator model, is the same at all points in the primary system. The system pressure is computed for each time step as an instantaneous function of the total helium mass in the primary system and the volume average temperature of helium In the primary system components. The hellum pressure drops across the core and across the reheatar stean generator module are determined at each calculational time step from $\Delta P=k W^{2} / \rho$ where the value of $k$ is determined from initial steady-state values of pressure drop, flow, and density in each component. The hclium circulator model computes the outlet pressure from the inlet pressure and the compressor map. The circulator hellum inlet pressure required by the circulator model Is set equal to the total system pressure.

Heat transfer to the PCRV 11ner cooling system is taken Into account in the following manner: the reheater helium in.iet temperature required by BLAST is calculated from the mixed mean core outlet temperature, an overall heat conductance from hellum through the PCRV Iiner Insulation to the coolin: water, and a cooling system "sink" 
temperature of $54^{\circ} \mathrm{C}\left(130^{\circ} \mathrm{F}\right)$. At tise inftial sieady-state operating conditions, the gas temperature through the duct from the core outlet to the reheater inlet is assumed to vary with position according to

$$
\frac{d T_{\text {gas }}}{d z}=\frac{-U A / \Delta Z}{U c_{\text {, He }}}\left(T_{\text {gas }}-T_{\text {sink }}\right)
$$

where $U$ is the overall heat transfer coefficient from the helium to the liner cooling system. Therefore

$$
\begin{aligned}
T_{\text {in, reheater }} & =e^{-U A / H c} p, H e T_{\text {out }, \text { core }} \\
& +\left[1.0-e^{-U A / W c} p, H e j T_{\text {sink }}\right.
\end{aligned}
$$

The value of UA for inftial steady-state conditions can be determined by Eq. (5.2) from infitial steady-state values of $T_{\text {in, reheater }}$ and $T_{\text {cut, core }}$. Equation (5.2) is then used at each time step to determine $T_{\text {in, rehsater }}$ from the primary system flow rate as determined by the helfum circulator turbine model and from the mixed mean core outlet hellum temperature as determined by the core model. This approach implicitly assumes that the value of UA, the overail conductance, is independent of flow. This is a reasonable assumption since the resistance to heat flow through the PCRV thermal insulation is significantly larger than the flow dependent helium film resistance at the duct wall. The above approach is also used to determine the helfum circulator inlet helium temperature from the calculated steam generator hellum outlet temperature. 
As has been mentioned, the feedwater flow rate is specified by the plant control systen and is varied to aintain the pressure at the high pressure turbine throttle valve at its set point. Since there is presently no feedvater pump wodel in ORTAP, it is assuned that the actual feedwater flow to the econonizer section of the steam generator lags the flow requested by the control system by $2.0 \mathrm{sec}$, 1.e.,

$$
\frac{d U_{F U}}{d t}=\frac{1}{2}\left(U_{F W, \text { Request }}-W_{F W}\right) \text {, }
$$

80

$$
\begin{aligned}
W_{F W}(t) & =H_{F W, \text { Request }}(t) \\
& +\left[H_{F H}(t-\Delta t)-W_{F W, \text { Request }}\right] e^{-\Delta t / 2.0} .
\end{aligned}
$$

This feedwater flow is provided at each time step to the BLAST steam generator model. The feedwater enthalpy at the economizer inlet, also required by the BLAST steam generator model, is determined in OF.TAP by the simulation of the feedwater heaters in the turbine generator plant widel. The pressure at the economizer inlet as a function of time is specifiod in the input to ORTAP. The main steam outlet pressure required by the BLAST simulation is provided by the calculation of steam pressure in steam line 1 (Fig. 3.3.1) by the turbine generator model. The Inlet steam-side pressure and enthalpy to the rehebter, also required by BLAST 18 deter ined in the turbine generator model for steam IIne 4 (Fig. 3.3.1). The reheater cutlet pressure 18 st equal to the pressure of steam line 3. Reheater Inlet flow is determined from the 
ideal gas flow equation [Eq. (3.8)] using the pressures in steam IInes 3 and 4 .

The plant control system deteraines the helius circulator speed comand baszd on the difference between the neasured main stean temperature =ini its set polnz, plus the feedwater flow feed-forward signal. Following a turbine trip, this cowand way be overridden if the circulator inlet pressure is less than a lov pressure set poini. ORTAP applies a flow rate dependent measurement time constant to the vilue of main steam outlet temperature as calculated by BLAST to account for sensor response. That is,

$$
\begin{aligned}
& T_{\text {measured }}(t+\Delta t)=T_{\text {calculated }} \\
& +\left[T_{\text {measured }}(t)-T_{\text {calculated }}\right] e^{-\Delta t / \tau_{c}},
\end{aligned}
$$

where

$$
\tau_{c}=17.5 \mathrm{sec}+2.19 \times 10^{-6}\left(125-100 \frac{\mathrm{w}_{\mathrm{ms}}}{\mathrm{w}_{\mathrm{ms}, 0}}\right)^{3.5},
$$

where $W_{m s}$ is the main steam flow and $H_{m s, o}$ is the main steam flow at $100 \%$ conditions. This flow dependent measurement time constant is also used for detertining the measured reheat steam temperature from the reheat steam temperature calculated by BLAST.

Currently the proportional, integral, and derivative gains for the controllers are those given in Ref. 6 for $100 \%$ power operation. When actual gain settings for the FSV reactor become avallable, they will be used in the FSV version of ORTAP. 


\section{SAYPLE TRASIERT}

The sample transient described here is presented ainly to tllustrate the wore inportant features of the code, show a conplete saiple Input data set, and deconstrate a fer of the characte istics of HTGR tcansients. The example chosen is a rod pair withdrawal accident with a subsequent reactor scran when the core power reaches 1407 . It is assumed that the reactor is initially at 1007 power, with nuclear characteristics corresponding to an end-of-equilibriun cycle core, a rod pair worth of $0.012 \Delta k$ (for the pair being withdrawn) and a total scram reactivity worth of $0.064 \Delta \mathrm{k}$. These conditions represent the nost conservative case from the standpoint of maximum fuel temperatures attained. It is also assumed that the normal flux contrrl system, which varies reactor power to maintain the reheat steam temperature constant, and the rod withdraw inhibit at $120 z$ power are inoperative.

Figures 6.1 through 6.5 show some of the results of the stmulation. The runaway rod pair beglns withdrawing at time $t=0$ from the fully inserted position at the normal withdrawal speed of $180 \mathrm{sec}$ frr full travel. The core power reaches the trip level of 1407 in $j 9 \mathrm{sec}$, after which the remaining rods driven in (requiring $152 \mathrm{sec}$ for full trave1), the feedwater flow is ramped down to $25 \%$ of full-flow at $0.5 \% / 8 e c$, and the turbine throttle valve is ramped to $10 \%$ of 1 ts nominal full-power position at a rate of $0.5 \% / \mathrm{sec}$. Two minutes after the reactor is tripped, the turbine is tripped also. As the high-pressure turbine flow is reduced, the main steam preasure Increases and the main oteam bypass (MSBP) system begins diverting steam to the flash tank in order to $11 \mathrm{mit}$ the pressure to $17.68 \mathrm{MPa}$ (2564 psia). In this example, 


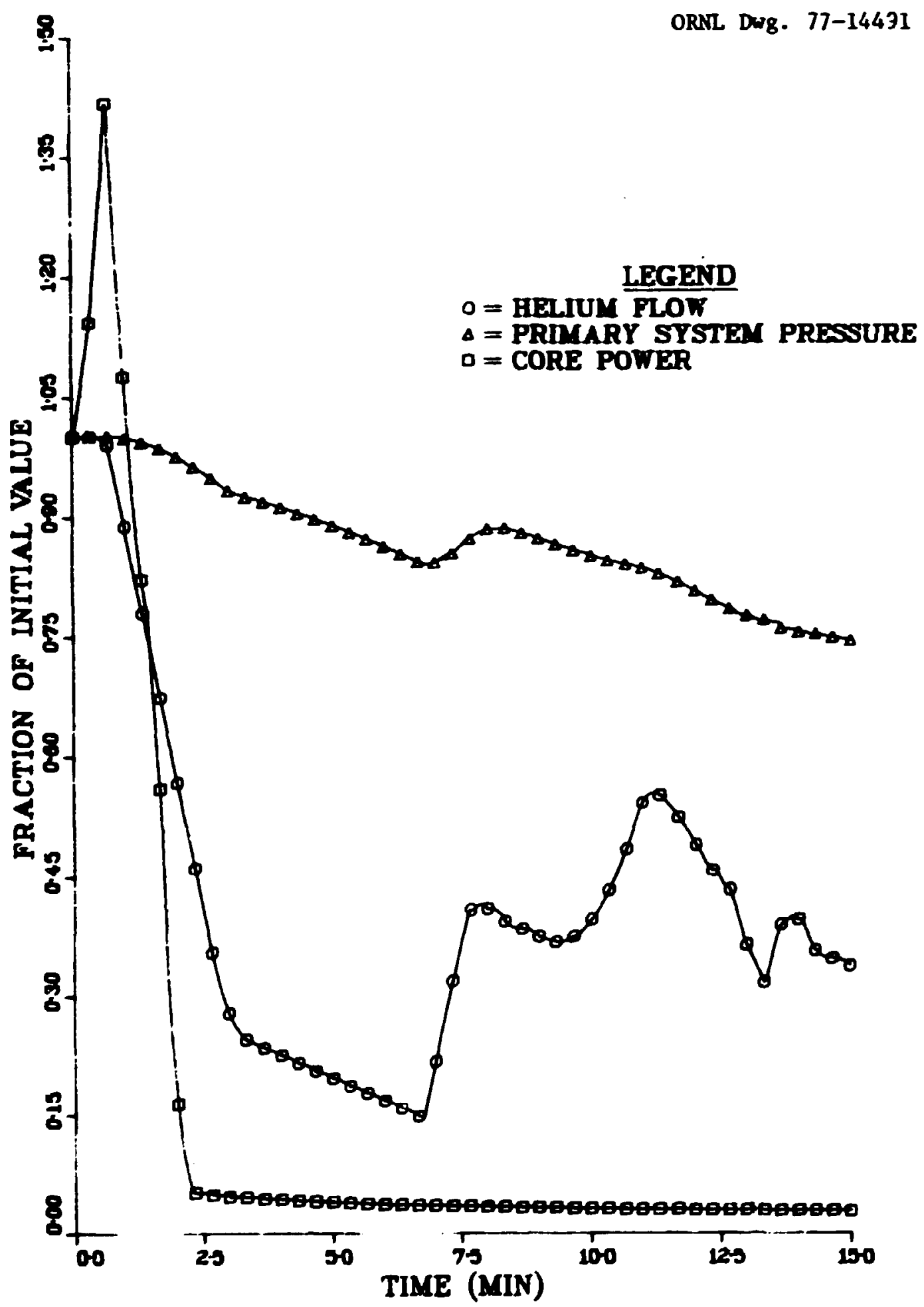

F1g. 6.1. Response of system parameters to a FSV rod-pair-withdrawal transient from an inftially fully inserted position. Trip signal $140 \%$ rated core power. 


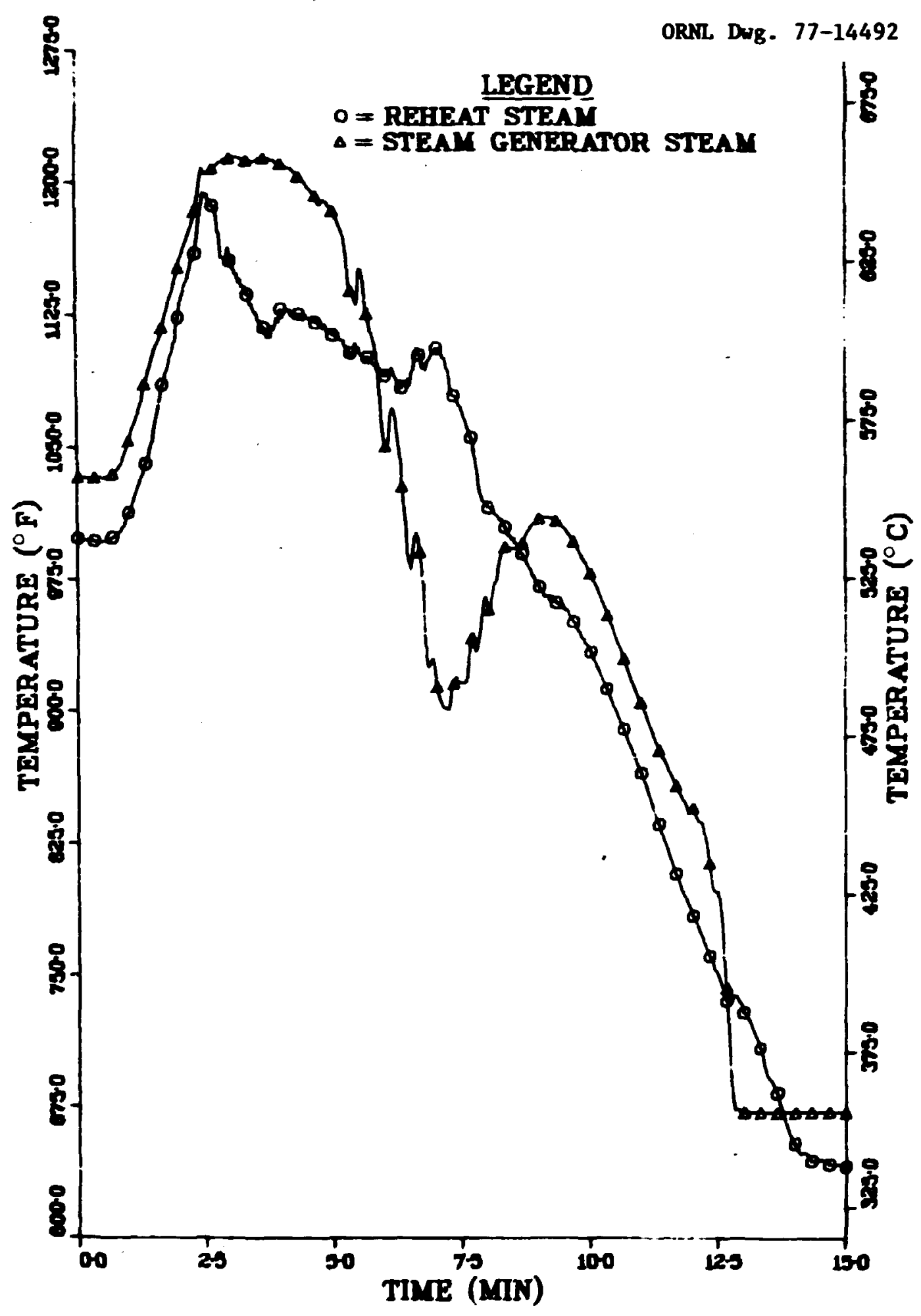

F1g. 6.2. Response of system parameters to a FSV rod-pair-withdrawal transient from an initially fully inserted postion. Trip signal 1407 rated core power. 


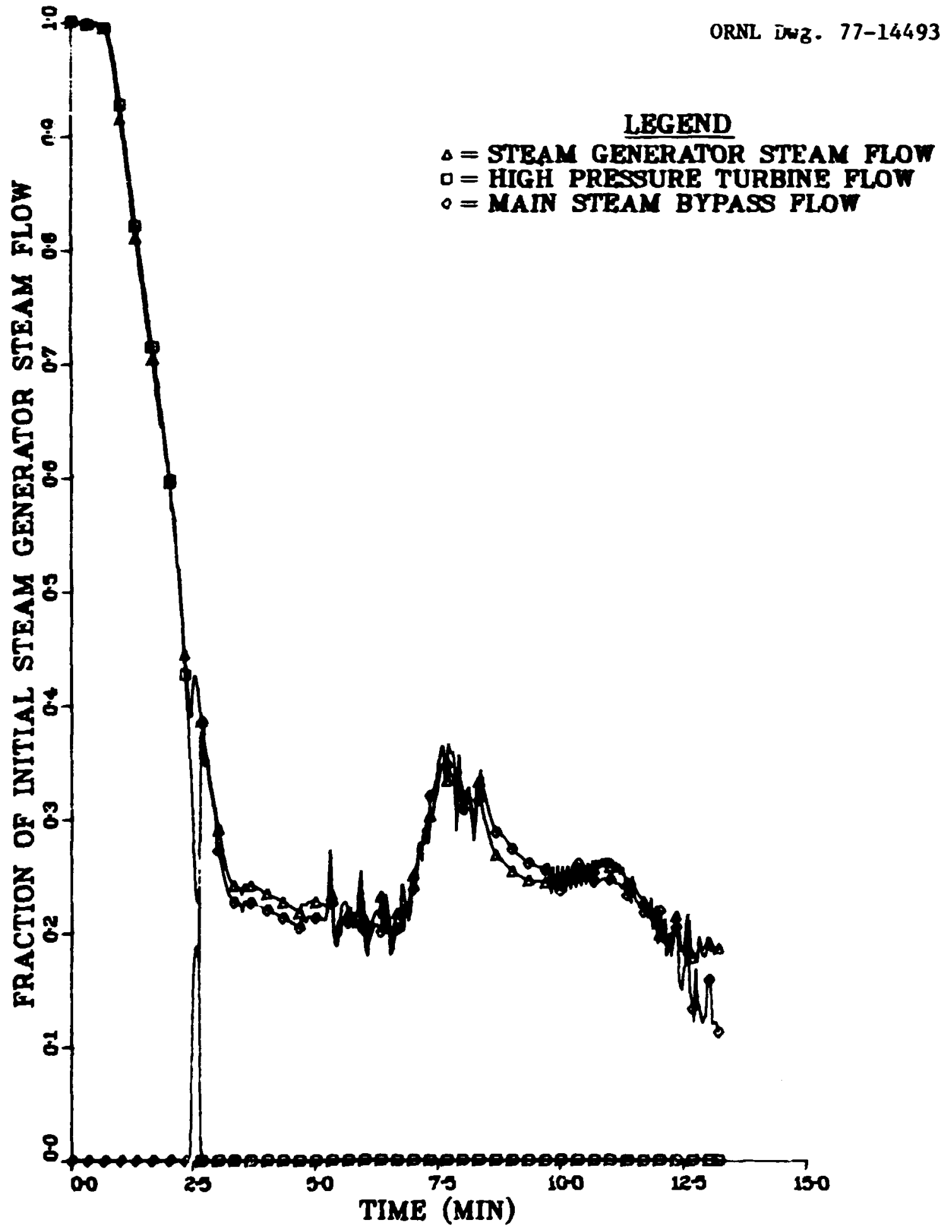

Fig. 6.3. Response of system parameters to a FSV rod-palr-withdrawal transient from an inftally fully inserted position. Trip signal $140 \%$ rated core power. 


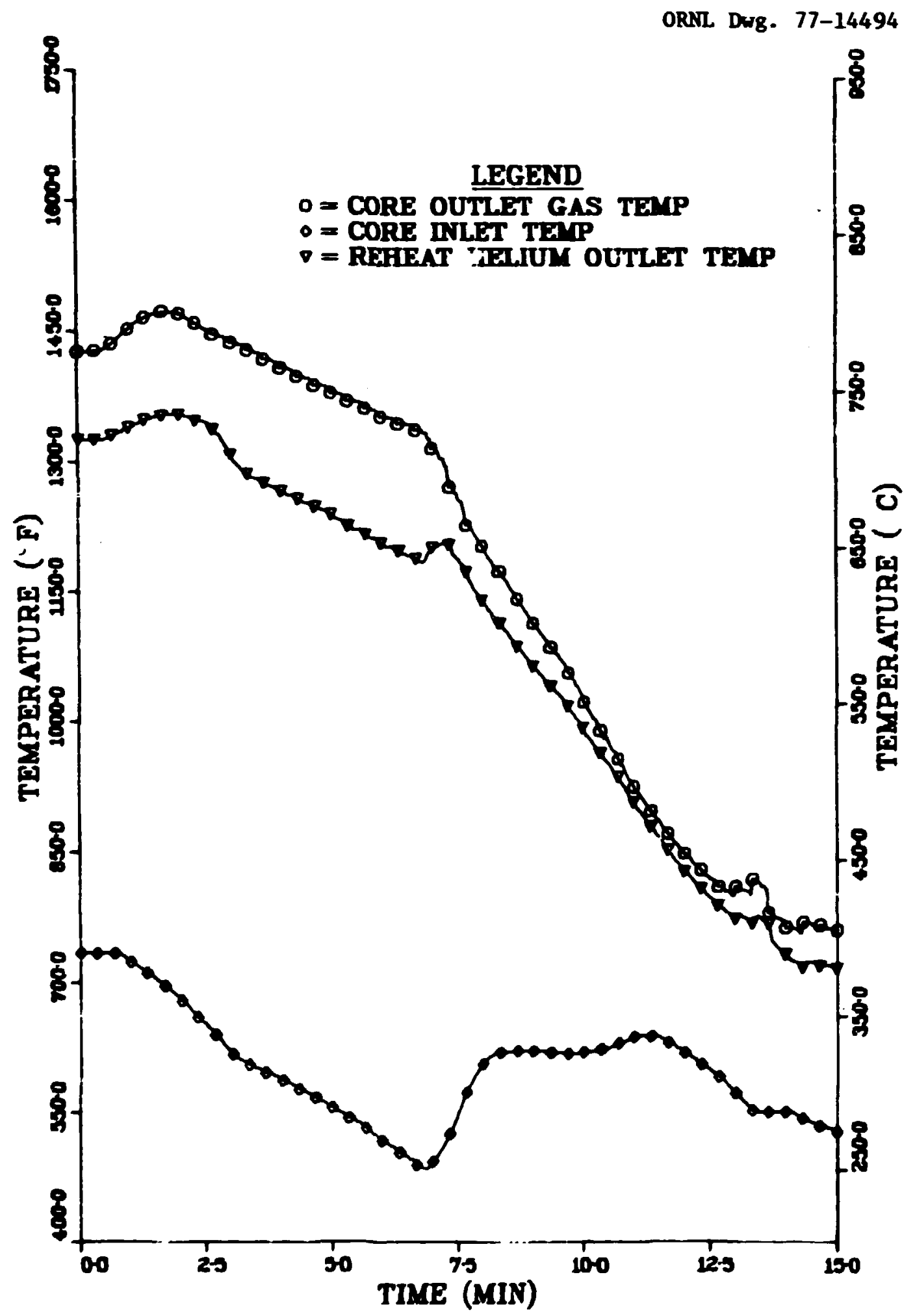

F1g. 6.4. Response of system parameters to a FSV rod-pair-withdrawal transient from an intilally fully inserted position. Trip signal $140 \%$ rated core power. 
ORNL Dwg. 77-14495

\&

i圆

ஜ‥

LEGEND

$\Delta=N A X$ CORE TEMP (ORECA)

0 = MEAN CORE TENP (ORECA)

$\nabla$ - MEAN MODERATOR TEMP (CORTAP)

$==$ MEAN FUEL TEMP (CORTAP)

$-8$

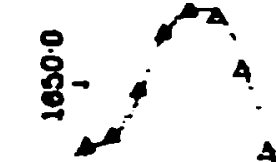

题

F员

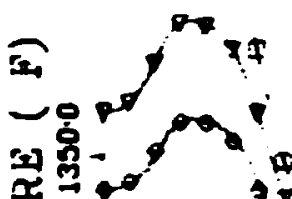

它

웡

목

齐

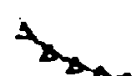

옹-

\&્.

员.

$\stackrel{\circ}{8}_{0-0}$

i.s

so

$7 \cdot 5$

100

is.s

영

总四

0

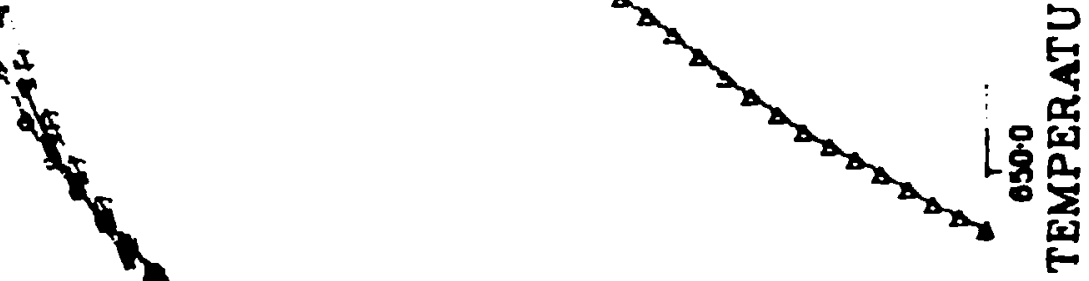

TIME (MIN)

Fig. 6.5. Response of system parameters to a FSV rod-pair-withdrawal transient from an initially fully inserted position. Trip signal $140 \%$ rated core power. 
the mavimu MSBP flow linit is not reached, so the vent valve is not opened.

The plot of normalized power (FIg. 6.1) peaks at 1.4 , where the trip occurs, and decreases eventually to the afterheat level. The relatively slow reduction in power is due to the slow-moving rods and the conservatively low value of cotal scran reactivity assumed. The ramp down of feedwater fiow following the reactor trip causes a similar ramp down of the helium flow (Fig. 6.1) since feedwater flow is the feedforward variable in the main steam temperature control system in which circulator speed (helium flow) is the deprindent variable (see Sect. 4). The helium flow continues to decrease until $t=6.7 \mathrm{~min}$, when it increases sharply after the main steam temperature has fallen below its setpoint. The sharpness of the increase is due to the fact that the controller output was saturated at its lower 1 imit for several minutes. The helium flow peaks at $t=11.2$ min in a final attempt to maintain the main steam temperature; after that, the circulator speed is limited by tive steam pressure available to the turbine drive. Figure 6.1 also shows the primary system (helium) pressure, which follows the trends of the average system temperature.

The reheater and steam generator out let steam temperatures (F1g. 6.2) Increase somewhat infially due to the increase in core helfum outlet temperature, but the primary cause of the sharp increases is the forced reduction of feedwater flow that occurs when the reactor is tripped. Other cases were run which showed the high sensitivity of the peak temperatures to the rate of power reduction after the trip. It would appear that a delay in the feedwater ramp down would be desirable 
in order to minimize the peak steam cemperatures. Note that the leveling off of the ain stean temperature after -12.5 minutes indicates that wet stean is exiting the stean generator.

Secondary cuoiant stean flows normalized to the initial stean generator outler stean flow are shown in Fig. 6.3. The stean generator and high pressure turbine (HPT) flows declige slightly at the start in response to the increasing heliu temperature. After the reactor trip, they are both ramped down quickly to about 257. The HPT flow goes to zere at $t=2.7$ min when the turbine is tripped. Since the feedwater flow is held constant at 257 after $t=3 \mathrm{~min}$, any variations of stean generator outlet flow after that time are due to changes in the water and steam inventories.

The primary loop helfum temperatures at the core inlet and outlet and the reheater outlet are shown in Fig. 6.4. As seen, little or no overshoot for any of these temperatures is predicted. The initial decrease in core inlet temperature is due to the reduction in helfum flow, which causes a closer approach of the steam generator helium outlet temperature to the nearly-constant feedwater inlet temperature. The rapid increase in core inlet temperature at $t=6.7 \mathrm{~min}$ is due to the increase in helium flow mentioned earlier. The core outlet temperature $T_{\text {co' }}$ as plotted, is dertved from both the CORTAP (single channel) and ORECA (mult1-channel) core models. Above $40 \%$ hellum flow, $T_{\text {co }}$ is the CORTAP output, and below $20 \%$ it is the ORECA output; in between, $T_{c o}$ is a flow-weighted average of the two. In this transient, the difference between the two model outputs was typically small, with a maximum difference of $-30^{\circ} \mathrm{C}\left(54^{\circ} \mathrm{F}\right)$. 
The ORECA model determines the average core temperature while CORTAP calculates separately the average fuel and the average graphite temperatures. ORECA also flags the peak temperature of the ORECA nodal masses. As discussed in Sect. 3.1 each of these nodal masses represents one of the six axial segments in each of the 37 refueling regions. The maximum core temperatures (ORECA) late in the transient typically occur in lowflow channels and thus take longer to cool down. The behavior of the average core temperatures in the two models is very similar.

Many other variations of the rod-withdzawal accident have been run and are reported In Refs. 11 and 12.

The sample transient was run with $0.1 \mathrm{sec}$ computation time steps and required 29 minutes of CPU time on the IBM 360/91. Including a one minute preaccident settling time, this corresponds to 1.8 minutes of CPU time per minute of simulated reactor time. Input instructions and the Input data set corresponding to this transient are shown in the Appendix. 


\section{FUTURE APPLICATIONS OF ORTAP}

ORTAP has been used to analyze system transients in the FSV plant resulting from uncontrolled removal of polion from the reactor core and from a postulated depressurization accident. ${ }^{13}$ In addition to these, ORTAP will be used to analyze transients resulting from a turbine trip, sudden reduction in feeduater flow and loss of primary coolant flow. When results of dynanics tests on the Fort St. Vrain reactor becowe avallable, comparisons will be made with ORTAP predictions, and, based on these comparisons, appropriate improvements in ORTAP will be made. With only very minor modificasions, ORTAP could be used to simulate large HTGRs. Also, with only slight modifications, ORTAP could be used to simulate a Gas Cooled Fast Breeder Reactor nuclear steam supply system.

\section{3EFERENCES}

1. A. Bardia and R. C. Potter, TAP: A Program toL inalysts of HTGR Nuclear Steam Supply System Performance Transients, GA-A-13248, January $30,1976$.

2. J. C. Cleveland, CORTAP: A Coupled Neutron Kinetics-Heat Transfer Digital Computer Program for the Dynamic Simulation of the High Temperature Gas Cooled Reactor Core, ORNL/NUREG/TM-39 (January 1977).

3. S. J. Ball, OKECA-I: A Digital Computer Code for Simulating the Dynamics of HTGR Cores for Emergency Cooling Analyses, ORNL/TH-5159 (1.976). 
4. R. A. Hedrick and J. C. Cleveland, BLAST: A Digital Computer Program for the Dynanic Staulation of the High Temperature Gas Cooled Reactor Reheater-Stean Cenerator Hodule, ORNL/NUREG/MM-38, (August 1976).

5. J. C. Cleveland, S. J. Ba11, R. A. Hedrick, and J. G. Delene, ORTAP: A Sinulator of High Temperature Gas-Cooled Reactor Nuclear Steam Supply System Dynamics, Proc. 1977 Sumer Computer S1mulation Conference, July 18-20, 1977, pp. 359-69.

6. E. A. Parziale, Overall Plant Control Systen Functional Design for the $2000 \mathrm{MU}(\mathrm{t})$ HTGR Plant, GA-A13630 (October 1975).

7. S. J. Ball and R. K. Adams, MATEXP: A General Purpose Digltal Computer Program for Solving Ordinary Differential Equations by the Matrix Exponential Method, ORNL-TM-1933 (August 1967).

8. J. G. Delene, A Digital Computer Code for Simulating the Dynamics of Demonstration Size Dual-Purpose Desalting Plants Using a Pressurized Water Reactor as a Heat Source, ORNL/TM-4104, (Sept. 1973).

9. Public Service of Colorado, Fort St. Vrain Reactor, Final Safety Analysis Report, Docket No. 50-267.

10. P. A. Secker and J. S. Gilbert, Status of CHAP: Comp's 1 te HTGR Analysis Program, LA-6180-SR (January 1976).

11. J. C. Cleveland, S. J. Ba11, R. A. Hedrick, J. G. Delene, and J. C. Conkiln, "Simulation of the Response of the Port St. Vrain High Temperature Gas-Cooled Reactor System to a Postulated Rod Withdrawal Accident," (To be published In the Proceedings of the ANS Thermal Reactor Safety Meeting, July 31 - Aug. 4, 1977, Sun Valley, Idaho). 
12. J. R. Brown and R. J. Nirschl, "Fort St. Vrain HTGR Maximum Rod Worth and Rod Withdrawal Accident Calculations for Reactor Thermal Powers from 27 to 1007 ," Gulf-GA-B10872, July 1.972 .

13. J. P. Sanders, High Temperature Gas-Cooled Reactor Safety Studies for the Division of Reactor Safety Research, Quarterly Progress Report, July 1, 1976 - September 30, 1976, ORNL/NUREG/TH-66. 


\section{APPENDIX}

\section{ORTAP INPUT DNSTRUCTIONS AND SAHPLE INPUT LISTING}

The input instructions and a sample input listing for a Fort St. Vrain simulation with ORTAP follow. The instructions can be wore easily understood by referring to the sample input listing. It is important to note that once the input is generated for a given plant-as it has been for FSV--there are very few changes necessary to run different transients. The bulk of the input describes initial steady-state conditions and plant design.

The intial portion of the input is that required for the corTaP core simulation.

Card No. 1 (FORMA 20A4)

Title card.

Card No. 2 (FORMAT 10X, 3I5)

$$
\begin{aligned}
& \text { IPOWER - Flag indicating hos core power prior to reactor trip will } \\
& \text { be determined. } \\
& 1=\text { core power is determined b; neutron flux controller. } \\
& 0=\text { core power is calculated from neutron kinetics equa- } \\
& \text { tions. } \\
& \text { IROD - This parameter is ignored if IPOWER = } 1 \text {. If IPOWER = }, \\
& \text { this parameter specifies whether control rod motion will } \\
& \text { introduce reactivity during the transient or not. } \\
& 0=\text { no control rod motion. } \\
& 1=\text { control rod motion. } \\
& \text { If IRoD = } 1 \text {, the user must supply a subroutine to be } \\
& \text { cailed from the main program specifying the reactivity }
\end{aligned}
$$


change due to rod motion as a function of time.

IPPNCH - Flag indicating whether core normalized power, inlet temperature, and helium flow vs time is to be punched on cards for a subsequent CORTAP highest-pover fuel region calculation.

$1=$ punch.

0 = do not punch.

Card No. 3 (FORMAT 10X, 5D10.4)

CORPWR - Initial thermal pover level in $M$.

FPC - Fraction of total thermal power deposited to coolant flowing thrcugh coolant channels in active core.

FPSR - Fraction of total thermal power deposited to coolant flowing through side reflector elements.

FPGT - Fraction of total thermal power deposited to coolant flowing through control rod channels.

FPAFS - Fraction of FPC $\star$ OORPWR that is generated in the entire axial length of an average fuel stick column.

Card No. 4 (FORMAT 10X, SD10.4)

FLow - Initial total core flow (lbmihr).

FFC - The fraction of the total core flow which flows through coolant channels.

FFSR - The fraction of the total core flow which flows through side reflector.

FFCT - The fraction of the total core flow which flows through control rod channels. 
FFACC - The fraction of FFC*FLAt which flows through the average coolant channel.

Card Ko. 5 (FORMT 10X, 7I5)

JMX - Muber of axial nodes in the active fuel portion of the unit cell.

NF - Nuber of radial nodes in the fuel stick.

MY - Number of radial nodes in the moderator.

NATR - Number of axial nodes in top reflector.

MABR - Number of axial nodes in bottom reflector.

NGTN - Number a axial nodes representing mass of graphite transferring heat with coolant flowing through a control rod channel.

NSRN - Number of axial nodes in side reflector.

The restrictions are

JMX* (NF+AM) + NATR + NABR $\leq 60$

NGTN $\leq 8$

NSRN $\leq 8$

Card No. 6 (FORMAT 10X, 2D10.4)

RPF - Radial porer peaking factor. This should be set equal to 1.0 since ORTAP uses the CORTAP core simulation for an average channel.

RFF - Radial ilow factor for coolant in cell being simulated. This should also be set equal to 1.0 .

Card No. 7 (FORMAT 10X, 4D10.4)

RF - Radius of the fuel stick (in.).

3AP - Width of gap between fuel stick and moderator (in.). 
NOTE: This is used to determine gap conductance,

$$
c_{\text {gap }}=\left(h_{\text {gap }} \star A\right) \text { 'GAP. }
$$

RM - Outer radius of graphite annulus in cylindrical cell

simulation (in.). This should be calculated to conserve the graphite volume in the triangular cell.

HEIGHT - Active core height (in.).

Card(s) No. 8 (FORMAT 10X, 7D10.4)

$\operatorname{AXZ}(\mathrm{J}), \mathrm{J}=1, \mathrm{JMAX}$ - The axial location of the centers of the nodal volumes in the active fuel (in.). By definition $z=0$ at the top of the active fuel column increasing in the dowmard direction.

Card (s) No. 9 (FORMAT 10X, 7D10.4)

$$
R(I), I=1, I M A X \text {, where } \operatorname{IMAX}=N F+N M \text {. }
$$

Distances from the fuel stick centerline to the radial surfaces of the nodes in the cylindrical representation of the unit triangular cell (in.).

Card No. 10 (FORMAT 10X, 2D10.4 2I5)

SRH - The height of the side reflector (in.).

SRAREA - The cross-sectional area of a side reflector symetry element $\left(i n .^{2}\right)$.

NCCSRE - The number of coolant channels in a side reflector element.

NSRC - The number of sidi reflector colums.

Card No. 11 (FORMAT 10X, D10.4)

TRT - The thickness of the top reflector (in.).

Card No. 12 (FORMAT 10X, D10.4, I5)

HDGT - The hydraulic diameter of the control rod channels (ft). 
NGT - The number of control rod channels.

Card No. 13 (FORHAT 10X, D10.4)

VOLGTT - The total volume of graphite which the user allows to transfer heat with the average control rod channel (in. ${ }^{3}$ ). This is used for heat capacity effects.

Card No. 14 (FORMAT 10X, 6D10.4)

RHOFUL - The density of the fuel stick $\left(1 \mathrm{bm} / \mathrm{ft}^{3}\right)$. See note.

RHOMOD - The density of the bulk moderator $\left(1 \mathrm{bm} / \mathrm{ft}^{3}\right)$. See note.

DENRAT - The ratio of the denstity of the graphitc in the fuel stick to the density of the graphite in the bulk moderator.

F - The volume fraction of the graphite in the fuel stick. RHOGT - The density of the graphite in the mass transferring heat with coolant flowing through the average control rod channel $\left(1 \mathrm{bm} / \mathrm{ft}^{3}\right)$. See note. RHOSR - The density of the side reflector $\left(1 \mathrm{bm} / \mathrm{ft}^{3}\right)$. See note. NOTE: If the temperature dependent heat capacities in subroutines CPFUEL AND CPMOD have units of $B t u / \mathrm{ft}^{3}-{ }^{\circ} \mathrm{F}$, the corresponding "densities" (RHGFUL and RHQMDD) should be input as 1.0. If it is desired to account for the larger graphite to fuel stick mass $\therefore$ ratio in the refueling region than in the unit cell, the value ingut for RHOYOD can be used to account for this .

Card No. 15 (FORMAT 10X, 3D10.4, IS)

BRT - The thickness of the bottom reflector (in.). BRCHAN - The radius of the coolant channel through the bottors reflector (in.). 
ABR - The cross-sectional area of the $t$ riangular graphite symetry element in the bottom reflector (in. ${ }^{2}$ ).

NCCELM - The number of coolant channels in the active fuel feeding the bottos reflector channel.

Card(s) No. 16 (FORMAT 10X, 7F 0.4)

$\operatorname{AXPF}(J), J=1, J M A X$ - The axial power peaking factors for the fuel stick.

Card No. 17 (FORMAT 10X, I5)

NINC - The number of neutron kfnetics time steps per heat transfer time step.

Card No. 18 (FORMAT 10X, 2D10.4, 2I5)

DELTMP - The maximum amount that any nodal temperature can change without recalculating the components of the $\underset{\sim}{A}$ matrix [Eq. (3.18)] $\left({ }^{\circ} \mathrm{F}\right)$. Some experimentation on this parameter by the user is advisable to minimize computer time while maintaining sufficient accuracy. In general, the "weaker" the temperature dependence of fuel and moderator conductivities and specific heats, the larger this value can be. DLMDOT - The maximum amount that the total core flow rate can change without recalculating the components of the A matrix [Eq. (3.17)] $(1 \mathrm{bm} / \mathrm{hr})$. No single value for this parameter can be recommended since the value which would maintain sufficient accuracy while keeping computer time as low as possible depends on how low the core flow becomes in any given transient. Some experimentation on this parameter with CORTAP by the user is advisable to minimize computer time while maintaining sufficient accuracy. 
NOUPDT - Flag for updating the A matrix [Eq. (3.17)] due to temperature dependence of its elements after each iteration on feedback reactivity.

$=0$ update

$=1$ do not update $\underline{A}$.

This option is somewhat obsolete and NOUPDT $=1$ is recommended. If NOUPDT $=0$ is used, problem execution time is greatly increased with essentially no improvement in accuracy.

NPT - Number of heat transfer time steps between printouts.

Card No. 19 (FORMAT 10X, 3010.4)

HGAP - The heat transfer coefficient of the gap between the fuel and moderator $\left(B t u / h r-f t^{2}-{ }^{\circ} F\right)$.

D - The hydraulic diameter of a coolant channel ( $f t$ ).

TINLET - The initial inlet temperature $\left({ }^{\circ} \mathrm{F}\right)$.

Card No. 20 (FORMAT 10X, I5, 2D10.4)

NG - Number of groups of delayed neutron precursors.

EPSLON - The convergence criteria for reactivity feedback. Recommend 1.0D-10.

RLSTAR - The average neutron lifetime from release to loss (sec).

Card No. 21 (FORMAT 10X, 7D10.4)

$\operatorname{BETA}(I), I=1, \ldots, N G$ - The delayed neutron fraction for precursor group I.

Card No. 22 (FORMAT 10X, 7D10.4)

RLMBDA(I), I=1,..,NG - The decay constant for precursor group $I\left(\sec ^{-1}\right)$. 
Card No. 23 (FORMAT 10\%, 2Di0.4)

TMRFF - The reference graphite temperature for reactivity feedback $\left({ }^{\circ} \mathbf{F}\right)$.

TFREF - The reference fuel stick temperature for reactivity feedback $\left({ }^{\circ} \mathrm{F}\right)$.

Card No. 24 (FORMAT 10X, D10.4, 5X, I5, D10.4)

This card contains information pertaining to the MATEXP integration technque. For further detafls see ref. 9.

$P \quad-$ Precisicn of $e^{A \Delta t}$ and $\left[e^{A \Delta t}-I\right] A_{\sim}^{-1}$. Recommend $10^{-6}$ or 1ess.

ITMAX - Maximum number of tezms in series approximation of $e^{A \Delta t}$. The value of 64 for this parameter is sufficient.

VAR - Maximum allowable value of largest coefficient matrix element $\star \Delta t \quad($ Recommend VAR=1.0).

Cards No. 25 (FORMAT 10X, 7D10.4)

$\operatorname{XICT}(I), I=1, \ldots, \operatorname{NET}$, where NET = IMAX \pm JMAX + NABR + NATR.

Inftial nodal temperatures in upper reflector, active fuel cell and lower reflector $\left({ }^{\circ} \mathrm{F}\right)$. These are determined by a CORTAP calculation.

Cards No. 26 (FORMAT 10X, 7D10.4)

$\operatorname{TBULK}(J), J=1, J E N D$, where JEND = NATR + JMAX + NABR.

Gas temperatures corresponding to each solid nodal increment in the upper reflector, the active fuel cell and the lower reflector. These are the temperatures from which the temperature dependent helfum transport properties are obtained $\left({ }^{\circ} \mathrm{F}\right)$. 
The input data required by the ORECA subroutine portion of ORTAP follows. This consists of one control card plus 55 cards containing tho core inftial nodal temperatures, which are normally provided by a opecial run of the ORECA code.

Card No. 1 (FORHAT 7F10.0, 2I2)

AL - Reference value of composite core heat diffusivity divided by the square of the characteristic length between nodes, $D_{H} /(\Delta x)^{2}, \min ^{-1}$. This assumes reference values of specific heat $c_{p}=0.33 \mathrm{Btu}-1 \mathrm{~b}^{-1}-{ }^{\circ} \mathrm{F}^{-1}$, conductivity $k=10$ $B t u-h r^{-1}-\mathrm{ft}^{-1}-{ }^{\circ} \mathrm{F}^{-1}$, and normally incorporates the enhanced Efective conductance and hexagonal geometry correction factor noted in ref. 3 .

QZ - Initial value of $\left[Q / M C_{p}\right]$ for an average refueling region, ${ }^{\circ} \mathrm{F} / \mathrm{min}$, using reference values of $c_{p}$ and $k$ noted above.

DP - Inftial pressure drop across the core, psi.

FSQ - Channel fJ.ow "skew factor" (0.C to 1.0$):$ set $=0.0$ to make all inftial refueling region flows equal; or $=1.0$ to make them proportional to the radial fower factor $Q R_{1 j}$; or in between as destred.

FFPRN - Fraction of Intial core flow below which core temperature maps are to be printed.

FFBEGC - Fraction of Initial core flow below which ORECA-derived core outlet temperatures begin to merge with CORTAP-derived core outlet temperatures in determining the best estimate value. 
FFENDC - Fraction of initial core flow below which only ORECAderived core outlet temperatures are used as the best estimate. At flow fraction values between FFBEGC and FFENDC, the CORTAP- and ORECA-cierived temperatures are weighted linearly with $\bar{l}$ low.

NTP - Number of ORTAP $\triangle t$ intervals between each ORECA computation.

JPF - Flag for channel flow and $\triangle P$ print-out at each time step. 1 = print.

$0=$ do not print.

Cards Nos. 2-56 (FORMAT 8F10.8)

Initial core temperature distributions. These 55 cards are normally punched by a previous run of ORECA:

( $[X P(I, J), J=1,8], I=1,55)$, where $J$ is the axial region index, and $I$ is the radial index ( 37 refueling regions plus 18 side reflector regions).

[Repeat sequence if desired.]

Other data which are incorporated in the ORECA program as DATA statements are the axial and radial power factors for each refueling region, flow iteration error limits, plus a variety of other data peculiar to the FSV design and construction which would not normally need to be altered.

The following describes the input required for the FSV turbine generator plant simulation in ORTAP.

Cards No. 1 (FORMAT 20A4)

Two title cards. 


\section{Card No. 2 (FORMAT I5)}

Number of stean generator modules feeding the high pressure turbine. For FSV set equal to 12 .

Card No. 3 (FORMAT 16I5)

$\operatorname{IND}(I), I=1,16$ - Set all = 0 except:

IW(3) = Number of time steps between $T-G$ plant printouts.

$\operatorname{IND}(9)=0$ for fixed throttle valve; = 1 for controlled electrical output.

$\operatorname{IND}(11)=1$ to disable reactor trip on He pressure $>753$ psia.

$\operatorname{IND}(13)=$ Number of time steps between summary print/punch.

$\operatorname{IND}(15)=1$ to disable reactor trip on 1407 power.

$\operatorname{IND}(16)=1$ to disable reactor trip on high reheat steam temperature.

Card No. 4 (FORMAT E10.3)

VLVH - Initial high pressure turbine throttle valve setting.

$$
0 . C=\text { full closed; } 1.05 \text { = valve wide open. }
$$

Card No. 5 (FORMAT E10.3)

WHP - Flow rate into high pressure turbine $(1 \mathrm{bm} / \mathrm{sec})$ at $t=0.0$.

Card No. 6 (FORMAT 4E10.5)

HH(I), I=1, .., 4 - Enthalpies: (Bru/1bm) at each numbered section

(see Fig. 3.3.1) in the high pressure turbine at $t=0.0$.

NOTF: Four values are necessary for the FSV simulation.

Card No. 7 (FORMAT 4E10.3)

$\mathrm{PH}(\mathrm{I}), I=1, \ldots, 4$ - Pressures (psia) at each numbered sectinn in

the high pressure turbine at $t=0.0$. NOTE: Four values

are necessary for the FSV simulation.

Cards No. 8 (FORMAT 6E10.3)

WLP(I), I=1,.., 14 - Flow rate $(1 \mathrm{bm} / \mathrm{sec})$ at various points in the 
turbine generacor plant downstream of the reheater at $t=0.0$. The numbering scheme used for the FSV simulation is described below and should be read in conjunction with Fig. 3.3.1:

WLP(1) - flow from point 3 to point 4 in intermediate pressure turbine.

WLP(2) - flow from point 4 of intermediate pressure turbine to point 5 of low pressure turbine.

HLP(3) - flow from point 6 to point 8 of low pressure turbine.

WLP(4) - flow from point 8 to point 10 of low pressure turbine.

KLP(5) - flow from point 10 to point 12 of low pressure turbine.

WLP(6) - flow from point 12 to point 14 of low pressure turbine.

WLP(7) - flow from point 4 of intermediate pressure turbine to botler feedpump (BFP) turbines.

WLP(8) - flow from point 4 of intermediate pressure turbind to feedwater heater 5 .

WLP(9) - extraction flow from point 6 of low pressure turbine.

WLP(10) - extraction flow from point 8 of low pressure turbine.

WLP(11) - extraction flow from point 10 of low pressure turbine. 
WLP(12) - extraction flow from point 12 of 100 pressure turbine.

WLP(13) - extraction flow from point 3 of internediate pressure turbine.

WLP(14) - flow from point 1 to point 3 of intermediate pressure turbine.

Cards No. 9 (FORMAT 6E10.3)

$H L(I), I=1, \ldots, 18$ - Enthalpy array (Btu/1bm) for Intermediate and 10w pressure turbines at numbered locations (see Fig. 3.3.1). To satisfy the turbine model set HL(15) $=$ HL(10), $H L(16)=H L(12), H L(17)=H L(14)$, and HL(18) = condenser outlet enthalpy (Btu/lbm).

Cards No. 10 (FORMAT 6E10.3)

$P L(I), I=1, \ldots, 18$ - Pressure (psia) array in intermedlate and low pressure turbines at numbered locations at $t=0.0$ (see Fig. 3.3.1). Set PL(15) $=\operatorname{PL}(10), \operatorname{PL}(16)=\operatorname{PL}(12)$, $\mathrm{PL}(17)=\mathrm{PL}(14)$ and $\mathrm{PL}(18)=$ condenser pressure.

Cards No. 11 (FORMAT 4E10.3)

PFPI - Pressure (psia) at feedpump turbine inlet at $t=0.0$.

HFPI - Enthalpy (Btu/1bm) at feedpurp turbine inlet at $t=0.0$.

HFP - Enthalpy (Btu/1bm) at feedpump turbine outlet at $t=0.0$.

PFP - Pressure (psia) at feedpump turbine outlet at $t=0.0$.

Cards No. 12 (FORMAT 6E10.3)

One card is required for cach feedwater heater (numbered as in F1g. 3.3.1) at $t=0.0$. The deaerator 18 considered feedwater heater 4. 


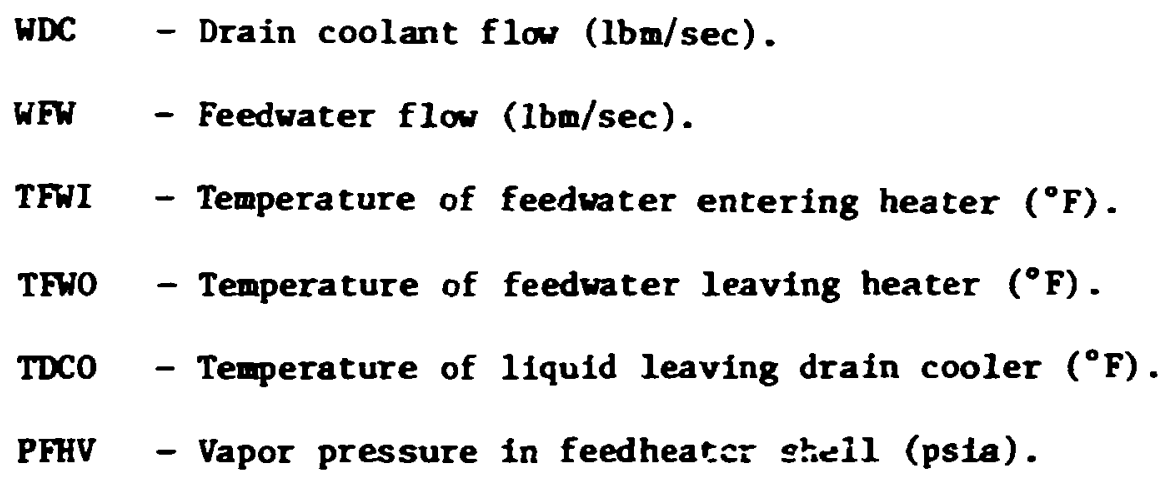

Cards No. 13 (FORMAT 4E10.3)

One card is required for each reedwater heater at $t=0.0$.

HFWC - Holdup time of feedwater in draincooler portion (sec).

HDC - Drain coolant holdup time (sec).

HFWE - Holdup time of feedwater in evaporator portion (sec).

HVFH - Steam holdup time on shell side of feedwater heater (sec). Card No. 14 (FORMAT 3E10.3)

HSG - Enthalpy (Btu/lbm) of steam exiting steam generator at $t=0.0$.

HSGI - Enthalpy (Btu/1bm) of feedwater entering steam generator at $t=0.0$.

PSG - Pressure upstream of high pressure turbine throttle valve at $t=0.0$. Set equal to pressure of steam line 1 (psia).

Card No. 15 (FORMAT 4E10.3)

HTV(I), I=1,.., 4 - Holdup time (sec) of steam lines 1 through 4 at $\mathbf{t}=0.0$.

Card No. 16 (FORMAT 4E10.3)

$\operatorname{PSL}(I), I=1, \ldots, 4$ - Pressure in the four stean lines at $t=0.0$ (ps1a). 
Card Ho. 17 (FORHAT 4E10.3)

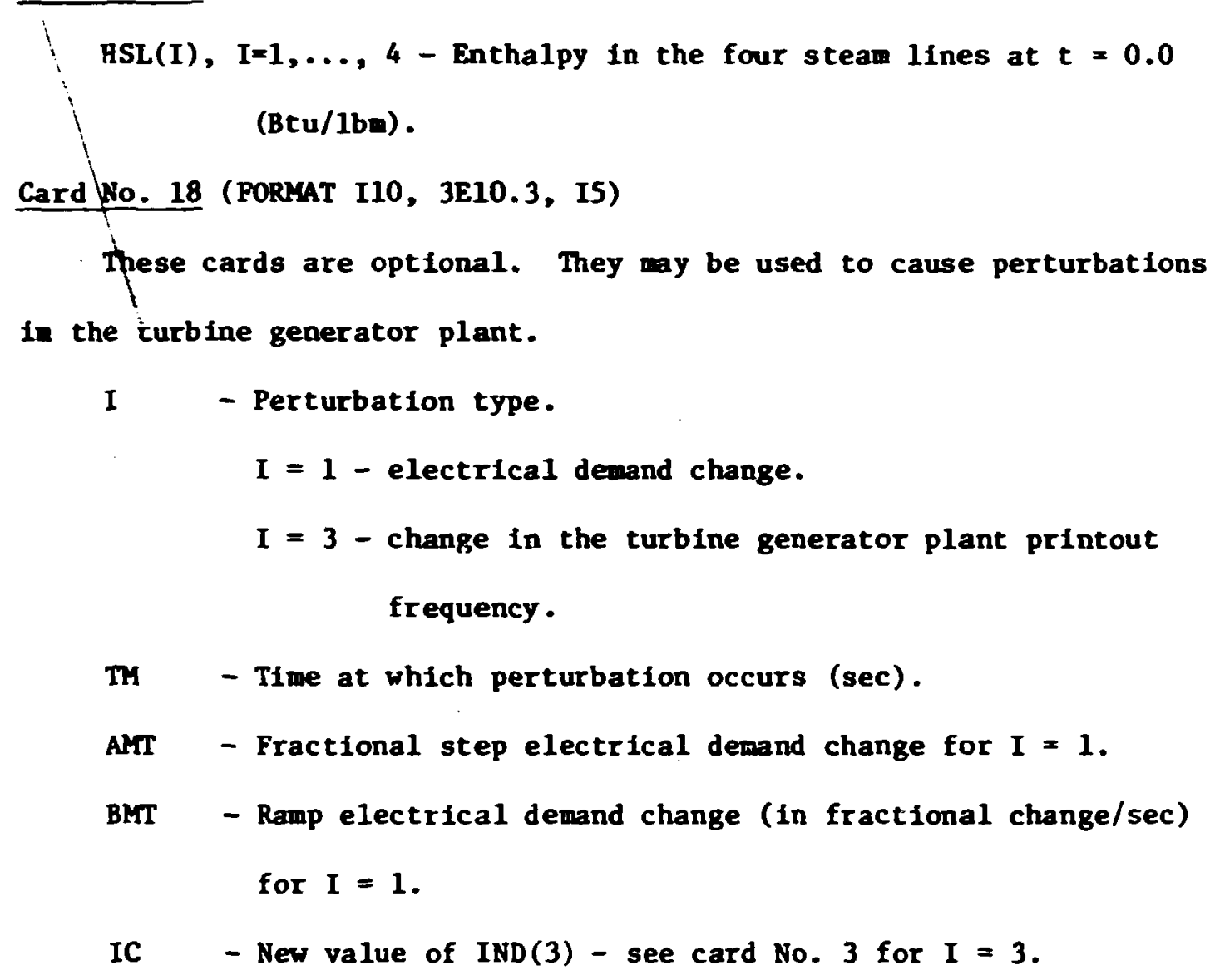

End turbine generator plant data with a 0 in colum 10 .

The input data required by the. BLAST portion of the ORTAP code is describer below. In determining a nodal arrangement such as in Fig. 3.2.1, the user should place rorlal boundaries where the tube material or diameter changes. Also, dividing a length of tube of a given material and diameter into more than one node provides finer calculational detall and therefore more accurate results.

The fizst entry on each data card required by BLA3T is a card series number. The data cards must be ordered numerically according to this series number. The series number is in format 110 , and the remaining entries are in 10 colum fields. 
CARD CARD

SERIES FORMAT

10NN I10,7D10.2

NN $=01, \ldots, k$, where $k \leq 9$

This card series provides the time step information for each component model in ORTAP. Time interval and associated time step information is given in ordered triplets: $\Delta t$ (sec), end of interval (sec), number of output edits during interval. Up to 20 ordered triplets are allowed.

The time step $\Delta t$ should be chosen less than nodal mass transport times, $M_{1} / W_{i}$ and at least factor of three less than the holdup times in the feedwater l:eaters and steam lines in the turbine generator plant simulation. The last card in series 10NN should te blank in columns 71-80.

$25 \mathrm{NN}$ Optionai steam generator conditions plot request series. See p. 70 .

70NN I10, 4D10.2, $3 \mathrm{II} 10 \mathrm{NN}=2 \mathrm{NN}_{\mathrm{w}}-1$, where $\mathrm{N}_{\mathrm{w}} \equiv$ water node number and $\left(1 \leq N_{w} \leq 20\right)$. Colums 11-20: Water node $N_{w}$ pressure guess (psia) for steady state search. Columns 21-30: Water node $N_{w}$ enthalpy guess (Btu/1bm) for steady state search. 
CARD CARD

\section{SERIES FORMT}

Colung 31-40: Water node $N_{w}$ flow area $\left(f t^{2}\right)$.

Columns 41-50: Tube length (ft) assoctated with water node $\mathrm{N}_{\mathbf{w}}$.

Coluns 51-60: Outlet position (1 = top, $0=$ brctom). NOTE: If rode is horizontal, input 0 in column 60 and column 70 . Normally the code uses the height (ft) of the associated helium node for the $\Delta z$ factor in the static head term in the water side momentum equation. However, the user can specify the value of $\Delta z$ by inputting, in integer form, $1000 * \Delta z$ in columins $61-70$. Columns 71-80: Number of helium node $\left(\mathbb{N}_{h}\right)$ which can transfer heat to this water node.

70KR 2I10, D10.2, $2 \mathrm{I} 10 \mathrm{KK}=2 \mathrm{~N}_{\mathrm{w}}$ - Continuation of information on card 70NN for water node $\mathrm{N}_{\mathrm{w}}$. Column 11-20: Tube type (specify 1, 2, or 3)

= 1 for carbon steel (SA-210-A1)

$=2$ for Incoloy 800

= 3 for Croloy (SA-213-T22)

Columns 21-30: Number of tubes which transfer heat with the helfum node referred 
CARD CARD

SERIES FORMAT to in colums $71-80$ of previous card.

Colums 31-40: Upstream node number

(= 201 for first reheater node)

(= 230 for first economizer node).

Columins 41-50: Downstream node number.

(= 215 for last reheater node).

Use $216,217, \ldots$, for mult iple reheater exits.

(= 251 for last superheater ncde).

Use $252,253, \ldots$, for multiple superheater exits.

75LL I10, 4D10.2, I10, D10.2, I 10
LL $=2 \star N_{w}-1$.

Colums 11-20: Mass flow rate ( $1 \mathrm{bm} / \mathrm{sec})$

in one tube coil in water node $N_{w}$ at

initial steady state conditions.

Columns 21-30: Tube inner radius (in.).

Columns 31-40: Tube outer radius (1n.).

Columns 41-50: Tube hydraulic diameter

(in.).

Columns 51-60: DNB correlation number

= 1 for user supplied correlation. See card series 9101.

$=2$ for $\mathrm{H}-3$, Jansen, Levy. See card series 9101. 
CARD CARD

SERIES FORMAT

$=3$ for B\&H-2, Barnett.

If 1,2 , or 3 is chosen, the code will not return to nucleate boiling once DNB has occurred.

$=4$ for user supplied correlation. See card series 9101.

$=5$ for $\mathrm{H}-3$, Jansen, Levy. See card sertes 9101.

= 6 for B\&W-2, Barnett.

If 4,5 , or 6 is chosen, the code w111

return to nucleate boiling once DNB has occurred.

Columns 61-70: Minimum heat transfer coefficient (Btu/hr-ft $\left.{ }^{2}-{ }^{\circ} \mathrm{F}\right)$.

Columns 71-80: Film boiling correlation key.

$$
\begin{aligned}
& \text { ( }=0 \text { for Dougal1-Rosenhow) } \\
& \text { ( } 1 \text { for Groeneveld). }
\end{aligned}
$$

75MM I10, 3D10.2

$M M=2 \star N=$ Continuation $c^{r}$ information on card 75LL for node $\mathrm{N}_{w}$.

Colums 11-20: Constant friction factor for node $\mathrm{N}_{w}$. This friction factor is added to that calculated from the Fanning friction factor curves to determine tho friction losses. 
CARD CARD

SERIES FORMAT

Columns 21-30: Ei D (Roughness to diameter ratio for tube; $D=$ inner diameter.)

Columns 31-40: Relative curvature of tubes associated with water node $N_{w}$. (Input 0.0 for straight tubes.)

80NN I16, 5D10.2, 2110 NN $=2 \star \mathrm{H}_{\mathrm{n}}-1$, where $\mathrm{N}_{h} \equiv$ helium node number and $\left(1 \leq \mathrm{N}_{\mathrm{h}} \leq 20\right)$.

Columns 11-20: Hellum node $\mathrm{N}_{h}$ pressure guess (psia) for steady state search.

Columns 21-30: Helium node $\mathrm{i}_{h}$ enthalpy guess (Btu/lbm) for steady state search.

Columns 31-40: Helium node $\mathrm{N}_{h}$ flow area $\left(\mathrm{ft} \mathrm{t}^{2}\right)$.

Columns 41-50: Helium node $N_{h}$ flow length (ft).

Columns 51-60: Height of nodal volume ( $f t$ ). Columns 61-70: Inlet position (1 = top, $0=$ bot $(0 \mathrm{~m})$.

Columns 71-80: Outlet position $(1=$ top, $0=$ bottom).

NOTE: Input 0 in column 70 and colımn 80 if node is horizontal.

80KK I10, D10.2, $2110 \quad K K=2 \star N_{h}$. Continuation of Information on card 80NN for node $\mathrm{N}_{h}$. 
CARD CARD

SERIES FORNAT
Columns 11-20: Nodal volume $\left(\mathrm{ft}^{3}\right)$.

Colums 21-30: Upstream nocie number.

(= 201 for first reheater node)

(= 215 for first tunnel node)

(= 230 for first superheater node)

Columns 31-40: Downstream node number.

(= 215 for last reheater node)

Use $216,217, \ldots$, for multiple reheater

exits.

(= 230 for last tunnel node)

(= 251 for last steam generator node)

Use $252,253, \ldots$, for multiple steam

generator exits.

85LL I10, 4D10.2, 2I10, $\mathrm{D} 10.2$

$L L=2 N_{h}-1$.

Columns 11-20: Mass flow rate $(1 \mathrm{bm} / \mathrm{sec})$ in

hellum node $N_{h}$ at inftial steady-state conditions.

Columns 21-30: Average tube OD (1n.) in helium node $\mathrm{N}_{h}$.

Columns 31-40: Constant friction factor.

Columns 41-50: A key used to determine

how the total helium side friction factor

is calculated. If $\leq 0.0$, only the con-

stant friction factor $\mathbf{W 1 1}$ be used to com-

pute friction 108ses. If $>0.0$, the code 
CARD CARD

SERIES FORMAT

will calculate a friction factor from the input values of the next four input vartables based on the correlation described in ref. 4 and add this to the constant friction factor to determine the friction losses. Columns 51-60: Number of inline rows of tubes in helfum node $N_{h}$. Columns 61-70: Number of staggered rows of tubes in helfum node $N_{h}$. Columns 71-80: Pitch to diameter ratiotransverse.

85MM I10, D10.2

$M M=2 * N_{h}$. Continuation of information on card 85LL for helium node $\mathrm{s}_{h}$. Columns 11-20: Pitch to diameter ratiolongitudinal.

$9001 \quad 3 I 10$

Columns 11-20: Number of first hellum node in the tunnel section between the reheater and the steam generator. Columns 21-30: Number of last hell $\mathrm{mm}$ node in tunnel.

9101 This card series is required if DNB correlation number on card series $75 \mathrm{LL}$ is 1,2 , 4 , or 5 . Otherwise, this series is omitted. 
CARD CARD

SERIES FORMAT

Colums 11-20: DNB flux (Btu/hr-ft ${ }^{2}$ ) for zero quality. Used only for DNB correlation number $=1$ or 4 .

Columens 21-30: Quality at which DNB

occurs. Used only for DNB correlation

number $=1$ or 4 .

Colums 31-40: Quality at which DNB flux becomes zero. Used only for DNB correlation number $=1$ or 4 .

Columns 41-50: "E factor" in Jansen-Levy correlation. See ref. 13. Used only for DNB correlation number $=2$ or 5.

$9201 \quad \mathrm{I} 10,2 \mathrm{D} 10.2$

Columns 11-20: Allowable temperature change $\left({ }^{\circ} \mathrm{F}\right)$ for water hefore recomputing thermodynamic transport properties. Columns 21-30: Allowable temperature change $\left({ }^{\circ} \mathrm{F}\right)$ for hellum before recomputing thermodynamic transport properties. It is recommended that both inputs on this card be 1.0 or less.

$180012 \mathrm{~T} 10,2010.2$

Steam generator (water side) inlet flow rate at $t=0.0$ in one tube. Columns 11-20: Number of pairs (time, flow rate) describing water side inlet flow rate 
CARD CARD

SERIES SORMAT

$18101 \quad 2110,6 \mathrm{D} 10.2$

$181 \mathrm{NN}$

$\mathrm{I} 10,7 D 10.2$

18201
$2110,2 \mathrm{D} 10.2$ vs time. Input 1 since feedwater flow rate

is determined by the plant contzoi system after time zero.

Columns 21-30: Time (sec). Input 0.0.

Columns $31-40$ : Flow rate $(1 \mathrm{bm} / \mathrm{sec})$ at

$t=0.0$

Steam generator (water side) inlet pressure vs time. Since there is no feedwater pump model, this must be specified for the entire time duration of the transient.

Colums 11-20: Number of pairs, (time, pressure) describing water side inlet pressure vs time.

Columns 21-30: Time (sec).

Columns 31-40: Pressure (psia).

Columns 41-50: Repeat Columns 21-30.

Colums 61-80: Repeat Columns 31-40.

$\mathrm{NN}=2, \ldots, k$, where $k \leq 42$. Continuation of card 18101.

Steam generator (water side) inlet enthalpy at $t=0.0$.

Columns 11-20: Number of pairs (time, enihalpy). Input I since feedwater heater 
CARD CARD

SERIES FORMAT

$185012 \mathrm{I} 10,2 \mathrm{D} 10.2$

$186012 \mathrm{I} 10,2 \mathrm{D} 10.2$

$18701 \cdot 2 \mathrm{I} 10,2 \mathrm{D} 10.2$ model determines this after time zero.

Colums 21-30: Tlme (sec). Input C.0.

Columns 31-40: Inlet enthalpy (Btu/1bm)

at $t=0.0$

Reheater (helium side) inlet flow rate at

$t=0.0$.

Columns 11. 20: Number of pairs (time, flow

rate) describing helium inlet flow rate vs

time. Input 1 since core model determines

this after time zero.

Columns 21-30: Time (sec).

Columns 31-40: F1ow rate $(1 \mathrm{bm} / \mathrm{sec})$ at

$\mathbf{t}=0.0$.

Reheater (helfum side) inlet pressure vs

time.

Columns 11-20: Number of pairs $\therefore{ }^{\circ}$,

pressure) describing hellum inlet essure

vs time. Input 1 since this is determined

by the circulator model after $t=0.0$.

Colımns 21-30: Time (sec). Input 0.0 .

Columns 31-40: Pressure (ps1a).

Reheater (helfum side) inlet enthalpy at

$t=0.0$. 
CARD CARD

SERIES FORMAT

\author{
Columns 11-20: Number of pairs (time, \\ enthalpy) describing hellum inlet enthalpy \\ vs time. Input 1 since this is determined \\ by core model after time zero. \\ Colums 21-30: Time (sec). \\ Columns 31-40: Inlet enthalpv (Btu/1bm) \\ at $t=0.0$.
}

In addition to the above required input, data cards may be supplied which request plots. Two data cards with sucressive card snries numbers are required for each plot. Card series numbers for the plot request cards begin with 2501, cannot exceed 2580 and must be consecurive. They must also be in numerical order with the required input cards, 1.e., they must follow the last IONN card.

The two cards required for each plot are:

First Card - (2I10, 3D10.2, I10, D10.2)

Colunins 1-10: Card series number.

Columns 11-20: IDPLT - a number defining variable to be plutted vs time. (See Table A-1)

Columns 21-30: XMINP - minfmum value of time (sec) for plot.

Columns 31-40: XMAXP - maximum value of time (sec) for plot.

Colume 41-50: XLPNP - length of plot (1n.) including vertical axis label. (Choose 8.5 for $(8-1 / 2 \times 11$ sheet.) 
Table $\dot{A}-1$. Values of IDPLT for card series 25N

IDPLT

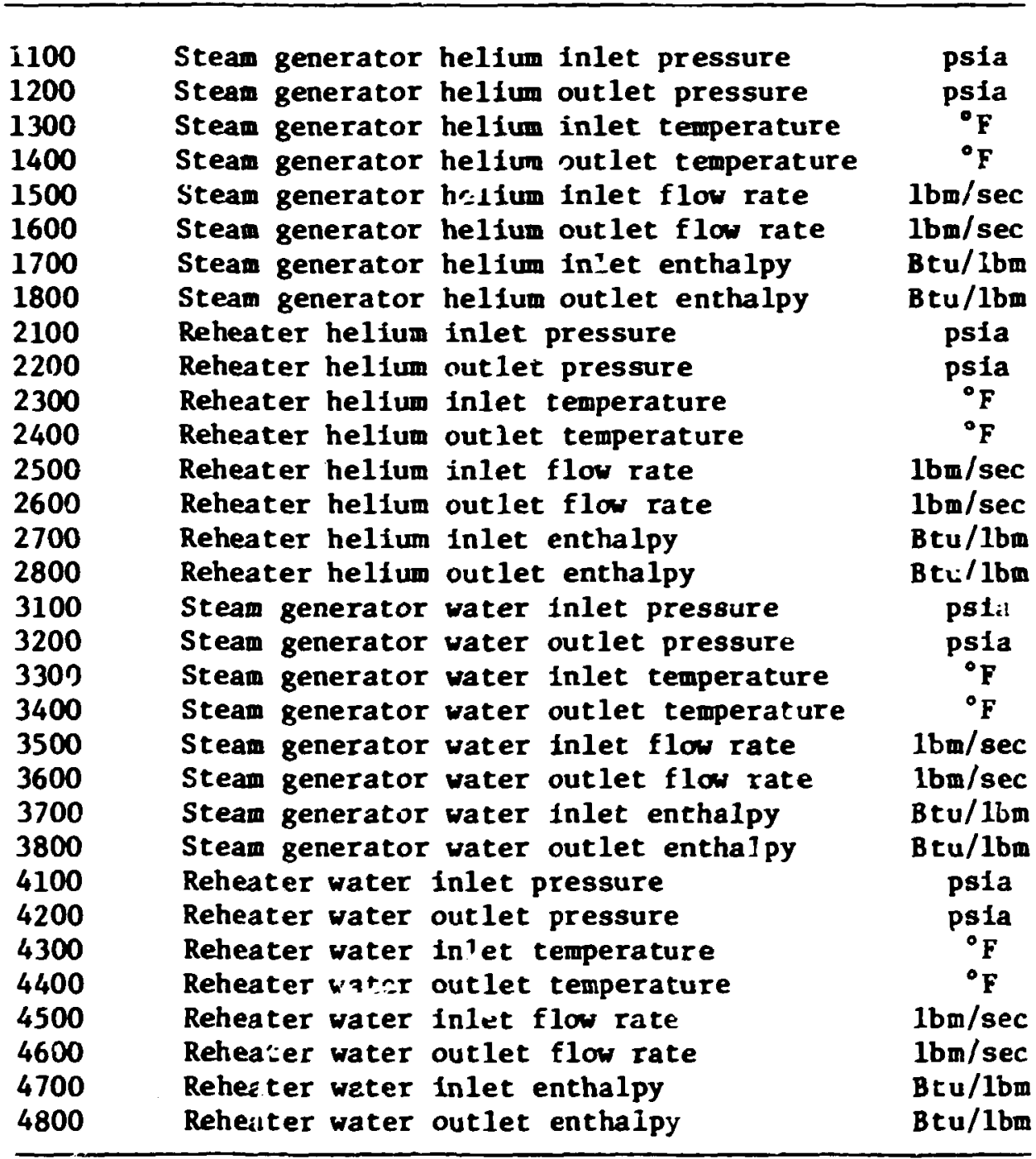


Table A-1. (Continued)

IDPLT NNN $\equiv$ NODE NUMBER

11NNN Helium pressure of node NNN, psia

12NNN Hellum temperature of node NN, ${ }^{\circ} \mathrm{F}$

13NNN Helium flow rate of node NNN, $1 \mathrm{bm} / \mathrm{sec}$

14NNN Heat flux from helium node $N N$, Btu/hr-ft ${ }^{2}$

16NNN Heat transfer coefficient for helium node $\mathrm{NNN}, \mathrm{Btu} / \mathrm{hr}-\mathrm{ft}^{2} \mathrm{o}^{\circ} \mathrm{F}$

ITNNN Helium density of node NNN, $1 \mathrm{bm} / \mathrm{ft}^{3}$

18NNN Tube wall temperature, helium side, for tube node NNN, ${ }^{\circ} \mathrm{F}$

22NNN Tube temperature for tube node NNN, ${ }^{\circ} \mathrm{F}$

31NNN Water fressure of node NNN, psia

$32 \mathrm{NNN}$ Water temperature of node NNN, ${ }^{\circ} \mathrm{F}$

33NNN Water flow rate of node $\mathrm{NNN}, 1 \mathrm{bm} / \mathrm{sec}$

$34 \mathrm{NNN}$ Heat flux to water for water node $\mathrm{NNN}, \mathrm{Btu} / \mathrm{hr}-\mathrm{ft}^{2}$

35NNN Quality in water node NNN

36NNN Heat transfer coefficlent for water node $\mathrm{NNN}, \mathrm{Btu} / \mathrm{hr}-\mathrm{ft}^{2}-{ }^{\circ} \mathrm{F}$

37NNN Water density in node $N N$, $1 \mathrm{bm} / \mathrm{ft}^{3}$

38NNN Tube wall temperature, water side, for tube nisde NNN, ${ }^{\circ} F$

$50000 \triangle P$ Helium node NiPLT to helfum node N2PLT, psid

$51000 \triangle P$ Hellum node N1PLT to water node N2PLT, psid

$52000 \triangle P$ water node N1PLT to water node N2PLT, psid 
Colums 51-60: Not used.

Colums 61-70: MrIN - minimum value of dependent variahle for plot.

Second Card - (110, 2D10.2, 2I10)

Columins 1-10: Value of series number on first card (for this plot) plus 1.

Colums 11-20: MMAXP - maximum value of dependent variable for plot.

NOTE: If YMINP and YMAXP are both Input as 0.0 , the code searches for a maximum and a minfmum.

Columns 21-30: YLENP - height of plot (in.) including horizontal axis labels. (Choose 11.0 for $8-1 / 2 \times 11$ sheet.)

Colums 31-40: N1PLT - if plotting $\triangle P$, N1PLT is the first node number for the $\Delta P$. Otherwise N1PLT $=$ 0 .

Colums 41-50: N2PLT - if plott1ng $\triangle P$, N2PLT is the second node number for the $\Delta P$. Otherwise N2PLT = 0. 
FSV ORTAP MOOEL I/3/7T ROD MITHDMAMAL FRON FULL IN ROOMRTH $=.012$

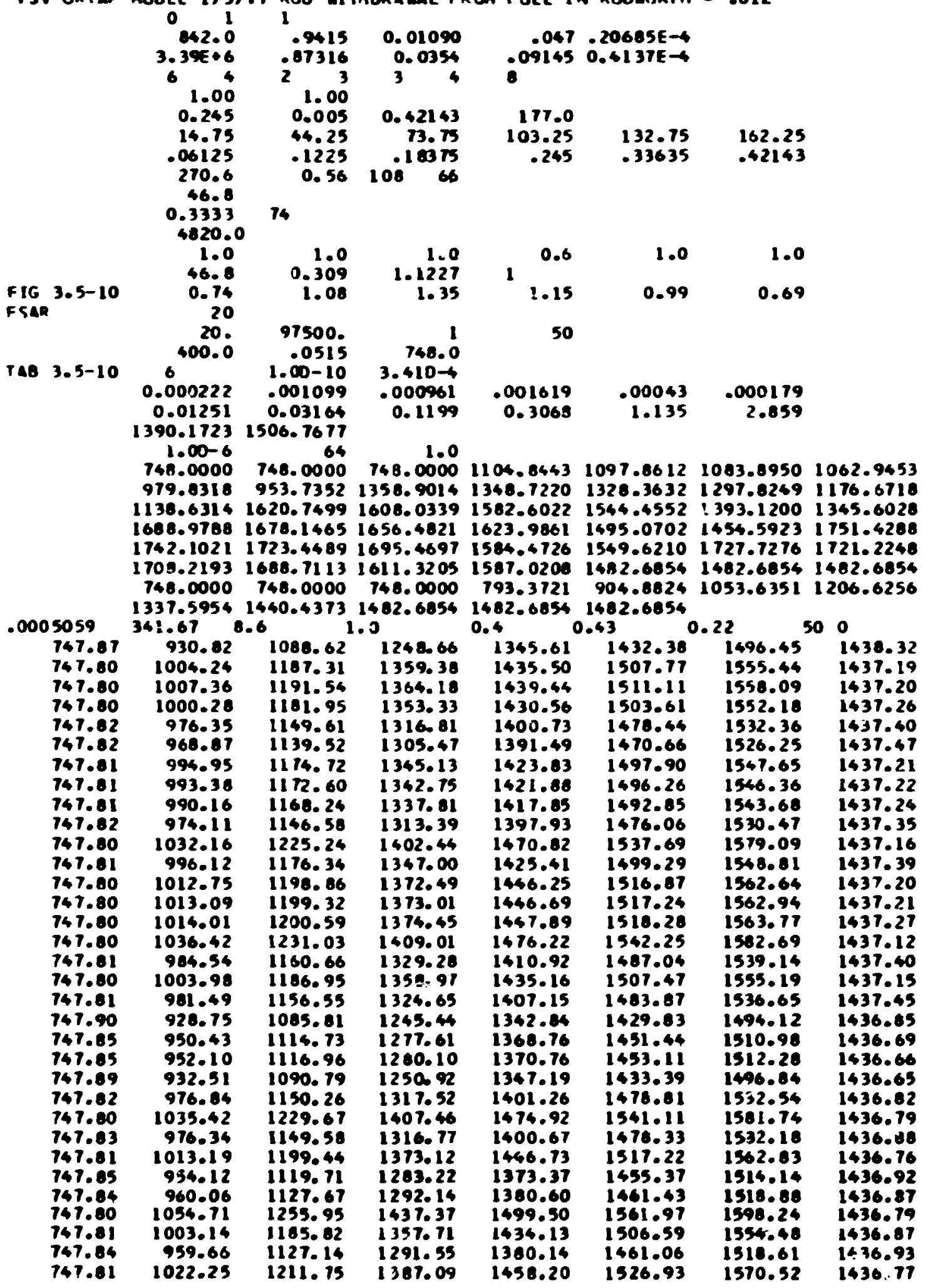




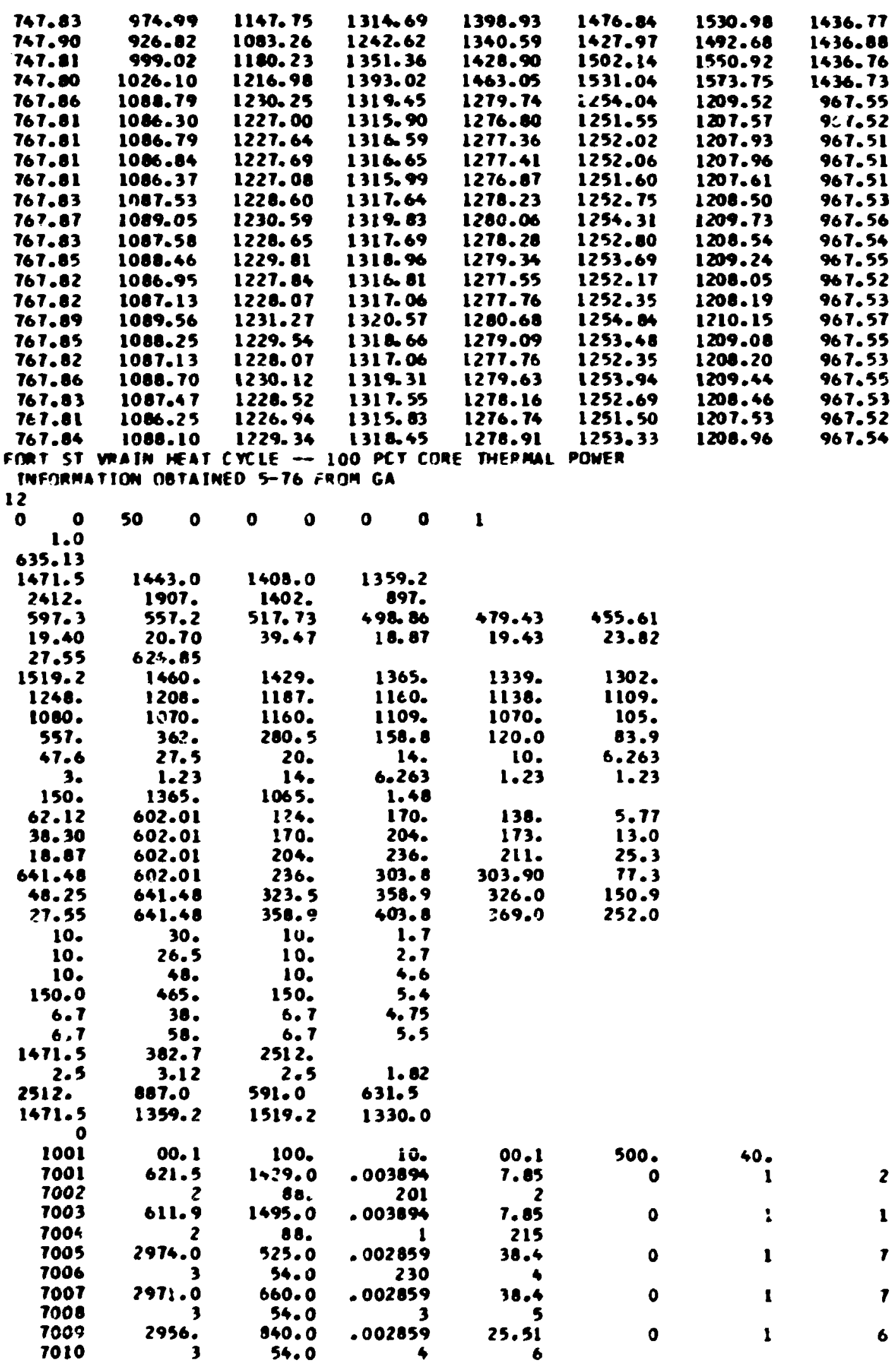




\begin{tabular}{|c|c|c|c|c|c|c|c|}
\hline $\begin{array}{l}7011 \\
7012\end{array}$ & 2951.0 & $\begin{array}{r}975.0 \\
54.0\end{array}$ & .0202859 & 11.69 & 0 & 1 & 5 \\
\hline 7013 & 2966.0 & 1030.0 & .002859 & 11.69 & 0 & 1 & 5 \\
\hline 7016 & & 56.0 & & & & & \\
\hline 7015 & 2936.0 & $11 \geq 3.0$ & .001650 & 12.15 & 0 & l & 4 \\
\hline 7016 & & $i^{r}$ & 7 & & & & \\
\hline $\begin{array}{l}7017 \\
7018\end{array}$ & 2884.0 & $\begin{array}{r}1 \geq 13.0 \\
54 .\end{array}$ & . 301650 & $\begin{array}{r}12.15 \\
10\end{array}$ & 0 & 1 & 4 \\
\hline 7019 & 2720 & 1420 & . 001899 & 49.81 & 1 & o & 3 \\
\hline $\begin{array}{l}7020 \\
7501\end{array}$ & $\begin{array}{r}2 \\
.59075\end{array}$ & 54. & $\begin{array}{r}9 \\
.5625\end{array}$ & $\begin{array}{r}251 \\
850\end{array}$ & 6 & 30 & \\
\hline 7502 & .0 & .001 & $\begin{array}{r}.3023 \\
.019\end{array}$ & & 6 & 30. & 0 \\
\hline 7503 & .59075 & .425 & .5625 & .850 & 3 & 30. & 0 \\
\hline 7504 & & .001 & .019 & & & & \\
\hline 7505 & .98822 & .362 & .5 & .726 & 6 & 30. & 0 \\
\hline $\begin{array}{l}7506 \\
7507\end{array}$ & $\begin{array}{r}-0 \\
.98822\end{array}$ & .003 & .016 & & 6 & 30 & \\
\hline $\begin{array}{l}7508 \\
7508\end{array}$ & $\begin{array}{c}-98822 \\
.0\end{array}$ & $.003^{.362}$ & $.016^{-3}$ & .724 & 6 & 30 & 0 \\
\hline $\begin{array}{l}7509 \\
7510\end{array}$ & - 98422 & $\begin{array}{r}.362 \\
.003\end{array}$ & .016 & .724 & 6 & 30 & 0 \\
\hline 7511 & .98822 & .362 & $\begin{array}{r}.010 \\
.5\end{array}$ & .124 & 6 & 30. & 0 \\
\hline 1512 & & .003 & .016 & & & & \\
\hline $\begin{array}{l}7513 \\
7516\end{array}$ & $\begin{array}{r}.98822 \\
.0\end{array}$ & $\begin{array}{l}.362 \\
.003\end{array}$ & .016 & .124 & 6 & 30. & v \\
\hline 7515 & .98822 & .275 & .5 & .55 & 6 & 30. & 0 \\
\hline 7516 & .0 & .004 & .012 & & & & \\
\hline 7517 & .98822 & .275 & .5 & .55 & 6 & 30. & 0 \\
\hline $\begin{array}{l}7518 \\
7519\end{array}$ & 998? & .004 & .012 & & & & \\
\hline $\begin{array}{l}7519 \\
7520\end{array}$ & $\begin{array}{r}.98122 \\
.0\end{array}$ & .295 & $.0 i^{5}$ & .59 & t & 30. & 0 \\
\hline 8001 & 669.4 & 2275.0 & 6.123 & 1.0 & 1.0 & 1 & 0 \\
\hline $800 ?$ & 180.0 & 201 & & & & & \\
\hline $\begin{array}{l}8003 \\
8004\end{array}$ & $\begin{array}{l}689.1 \\
180.0\end{array}$ & 2180.0 & $\begin{array}{r}6.123 \\
215\end{array}$ & 1.0 & 1.0 & $\mathbf{t}$ & 0 \\
\hline 8005 & 688.6 & 2090 & 5.782 & 4.0 & 4.0 & $\mathbf{l}$ & 0 \\
\hline $\begin{array}{l}8006 \\
8007\end{array}$ & $\begin{array}{l}600.0 \\
608.3\end{array}$ & $\begin{array}{r}230 \\
2018.0\end{array}$ & 0.562 & 1.0 & 1.0 & & 0 \\
\hline 8008 & 180.0 & & & & & 1 & 0 \\
\hline $\begin{array}{l}8009 \\
8010\end{array}$ & $\begin{array}{c}688.0 \\
540 .\end{array}$ & 1923.0 & $\begin{array}{r}6.542 \\
6\end{array}$ & 2.0 & 2.0 & $\mathbf{l}$ & 0 \\
\hline Bo1! & 687.3 & 1330.0 & 6.542 & 4.0 & 4.0 & $\mathbf{I}$ & J \\
\hline 8013 & 686.7 & 1594.3 & 3.542 & 3.0 & 3.0 & 1 & 0 \\
\hline $\begin{array}{l}0116 \\
8015\end{array}$ & 540.0 & $2140^{6}$ & 251 & & & & \\
\hline $\begin{array}{l}8015 \\
8016\end{array}$ & $\begin{array}{r}688.9 \\
200 .\end{array}$ & $\begin{array}{r}2140.0 \\
215\end{array}$ & $\begin{array}{r}6.542 \\
9\end{array}$ & 1.0 & 1.0 & 1 & 0 \\
\hline $\begin{array}{l}8017 \\
8018\end{array}$ & $\begin{array}{r}688.85 \\
200.0\end{array}$ & 2140.0 & $\begin{array}{r}0.542 \\
10\end{array}$ & 1.0 & 1.0 & 1 & 0 \\
\hline 8019 & 688.80 & 2140.0 & 0.542 & 1.0 & 1.0 & $\mathbf{l}$ & 0 \\
\hline $\begin{array}{l}8020 \\
8501\end{array}$ & $\begin{array}{r}200.0 \\
7 n .936\end{array}$ & 1.125 & $\begin{array}{l}230 \\
0.0\end{array}$ & 1.0 & 4 & 2 & 1.6 \\
\hline 5502 & 1.4 & & & & & & \\
\hline $\begin{array}{l}8503 \\
8504\end{array}$ & $\begin{array}{r}78.936 \\
1.4\end{array}$ & 1.125 & 0.0 & 1.0 & 4 & 2 & 1.4 \\
\hline $\begin{array}{l}8505 \\
8506\end{array}$ & $\begin{array}{r}78.936 \\
1.44\end{array}$ & 1.0 & 0.0 & 1.0 & 15 & 5 & 1.48 \\
\hline $\begin{array}{l}\text { A507 } \\
8508\end{array}$ & 78.936 & 1.0 & 0.0 & 1.0 & 15 & 5 & 1.42 \\
\hline 8509 & 18.936 & 1.0 & 0.0 & 1.0 & 15 & s & 1.42 \\
\hline $\begin{array}{l}8510 \\
8511\end{array}$ & $\begin{array}{r}1.47 \\
78.936\end{array}$ & 1.0 & 0.0 & 1.0 & 15 & 5 & 1,42 \\
\hline 8512 & 1.47 & & & & $\ldots$ & & 0.7 \\
\hline $\begin{array}{l}8513 \\
8514\end{array}$ & $\begin{array}{r}78.936 \\
1.47\end{array}$ & 1.0 & 0.0 & 1.0 & 15 & 5 & 1.42 \\
\hline 0515 & 78.936 & 1.0 & 0.0 & -1.0 & 0 & 0 & 1.40 \\
\hline $\begin{array}{l}\text { 8517 } \\
\text { Asid }\end{array}$ & $\begin{array}{r}18.936 \\
1.40\end{array}$ & 1.0 & 0.0 & -1.0 & 0 & 0 & 1.40 \\
\hline
\end{tabular}




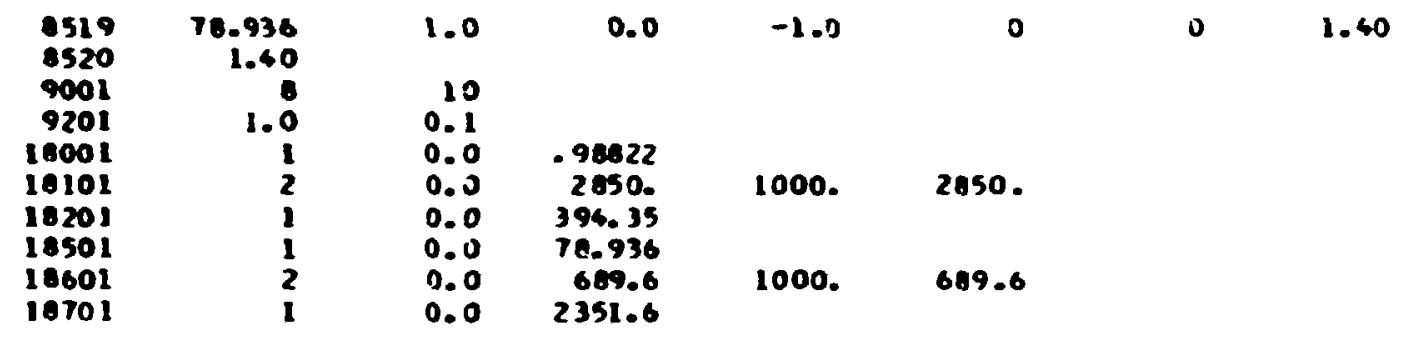

